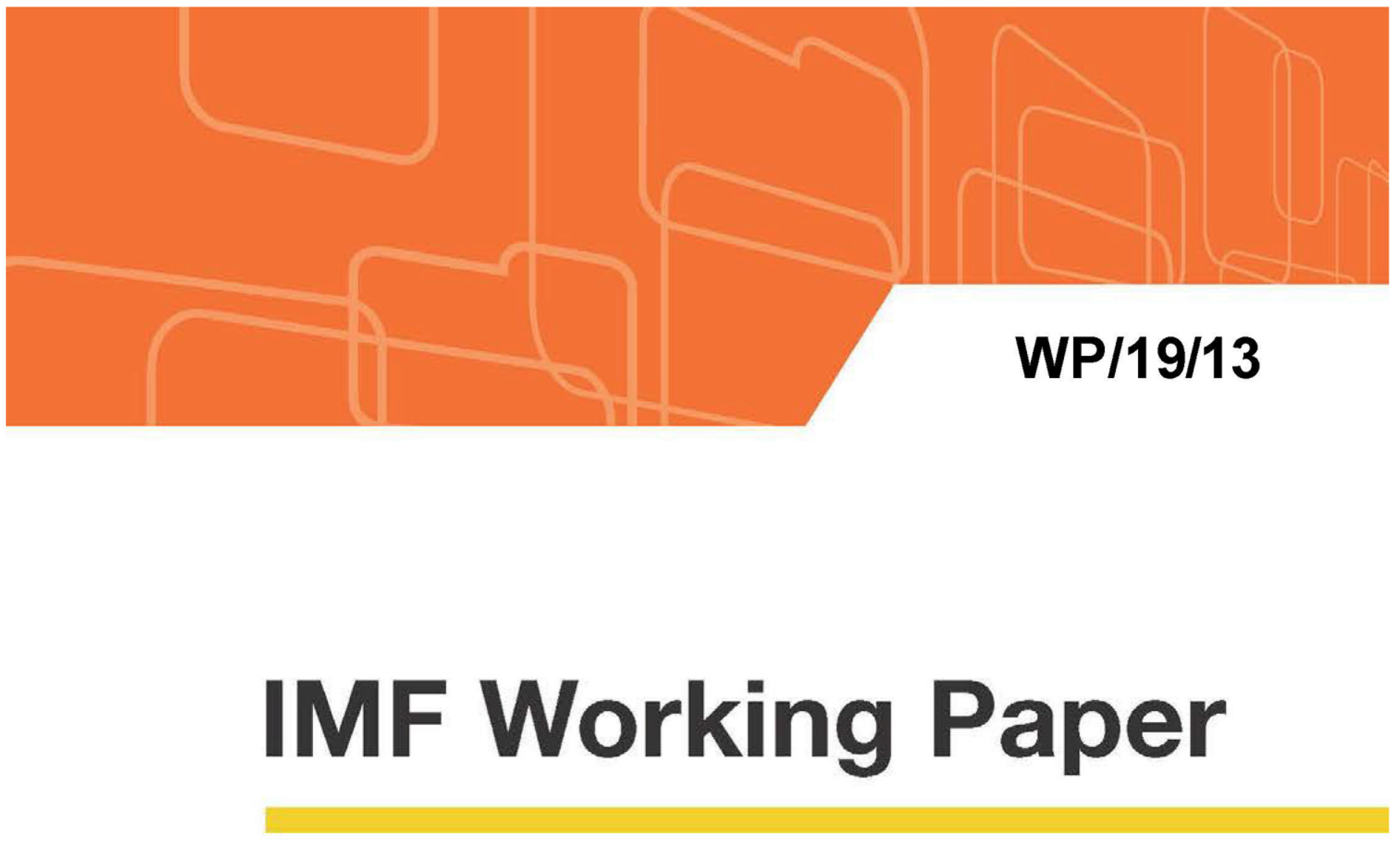

\title{
Corporate Tax Reform: From Income to Cash Flow Taxes
}

by Benjamin Carton, Emilio Fernandez-Corugedo, and Benjamin Hunt

IMF Working Papers describe research in progress by the author(s) and are published to elicit comments and to encourage debate. The views expressed in IMF Working Papers are those of the author(s) and do not necessarily represent the views of the IMF, its Executive Board, or IMF management. 


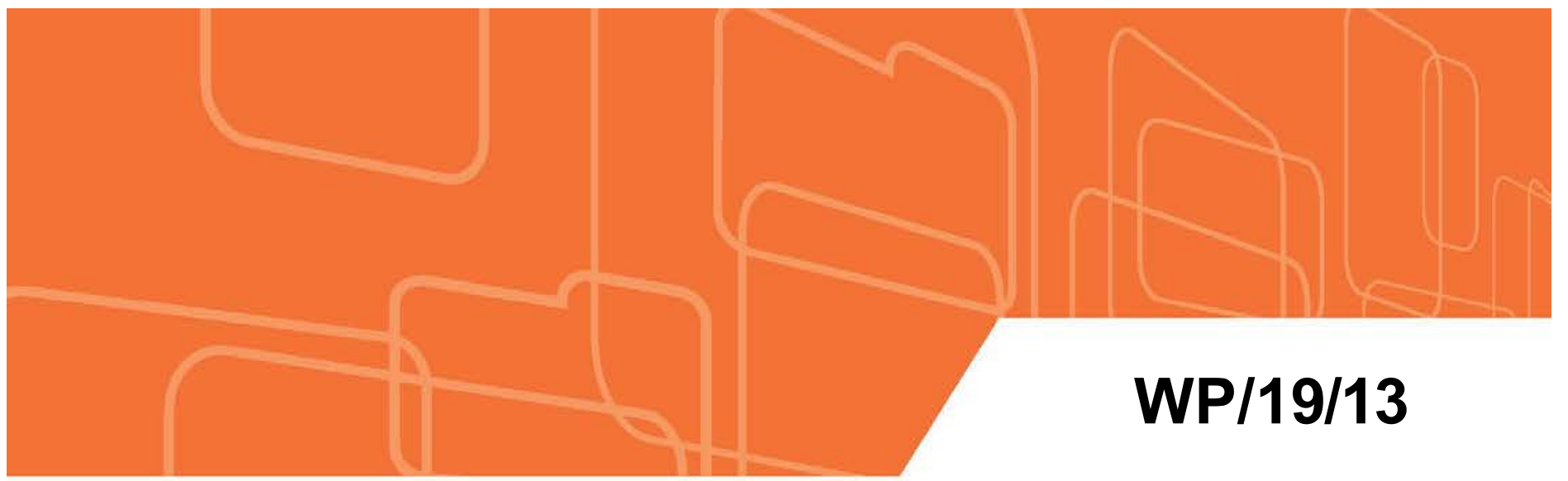

\section{IMF Working Paper}

\section{Corporate Tax Reform: From Income to Cash Flow Taxes}

by Benjamin Carton, Emilio Fernandez-Corugedo, and Benjamin Hunt

IMF Working Papers describe research in progress by the author(s) and are published to elicit comments and to encourage debate. The views expressed in IMF Working Papers are those of the author(s) and do not necessarily represent the views of the IMF, its Executive Board, or IMF management.

I N T E R N A T I O N A L M O N E T A R Y F U N D 


\title{
IMF Working Paper
}

\author{
Research Department
}

\section{Corporate Tax Reform: From Income to Cash Flow Taxes \\ Prepared by Benjamin Carton, Emilio Fernandez-Coruge do, and Benjamin Hunt}

Authorized for distribution by Benjamin Hunt

January 2019

IMF Working Papers describe research in progress by the author(s) and are published to elicit comments and to encourage debate. The views expressed in IMF Working Papers are those of the author(s) and do not necessarily represent the views of the IMF, its Executive Board, or IMF management.

\begin{abstract}
This paper uses a multi-region, forward-looking, DSGE model to estimate the macroeconomic impact of a tax reform that replaces a corporate income tax (CIT) with a destination-based cash-flow tax (DBCFT). Two key channels are at play. The first channel is the shift from an income tax to a cash-flow tax. This channel induces the corporate sector to invest more, boosting long-run potential output, GDP and consumption, but crowding out consumption in the short run as households save to build up the capital stock. The second channel is the shift from a taxable base that comprises domestic and foreign revenues, to one where only domestic revenues enter. This leads to an appreciation of the currency to offset the competitiveness boost afforded by the tax and maintain domestic investment-saving equilibrium. The paper demonstrates that spillover effects from the tax reform are positive in the long run as other countries' exports benefit from additional investment in the country undertaking the reform and other countries' domestic demand benefits from improved terms of trade. The paper also shows that there are substantial benefits when all countries undertake the reform. Finally, the paper demonstrates that in the presence of financial frictions, corporate debt declines under the tax reform as firms are no longer able to deduct interest expenses from their profits. In this case, the tax shifting results in an increase in the corporate risk premia, a near-term decline in output, and a smaller long-run increase in GDP.
\end{abstract}

JEL Classification Numbers: E12; E17; E52; E62; F41; F47

Keywords: tax policy; business taxation, corporate leverage, dynamic stochastic general equilibrium models; macroeconomic interdependence

Authors’ E-Mail Addresses:BCarton@imf.org;EFernandezCorugedo@imf.org; BHunt@imf.org; 


\section{Contents}

I. Introduction

II. Prior Studies on CIT Reforms in General Equilibrium Models

III. On the desirability of (Destination Based) Cash-Flow Taxes: Intuition

A. Capital Market Distortions $\underline{8}$

B. Labor Market Distortions

C. Export and Import Price Distortions $\underline{10}$

IV. Tax Reform Scenarios $\underline{10}$

A. Scenario 1: Replacing a CIT by a CFT (No financial Frictions) 11

B. Scenario 2: Replacing a CIT by a DBCFT (No financial Frictions) $\underline{14}$

C. Scenario 3: All Countries Replacing a CIT by a DBCFT (No financial Frictions) $\underline{17}$

D. Scenario 4: Replacing a CIT by a DBCFT (With Financial Frictions) 19

V. Conclusions $\underline{23}$

VI. References 24

I. Appendix: Summary of the Global Integrated Monetary and Fiscal Model $\underline{27}$

A. Household Sector $\underline{28}$

B. Production Sector 29

C. Financial Sector 29

D. International Dimensions and Spillovers $\underline{30}$

E. Fiscal and Monetary Policy $\underline{30}$

F. The Calibration of GIMF $\underline{31}$ 


\section{INTRODUCTION}

An ample and wide-ranging literature on tax reform exists. This includes the examination of various tax instruments (expenditure, income/earnings, wealth, and flat taxes) and alternative methodologies to examine the impact of reforms (partial vs general equilibrium, simulationbased vs empirically-based). Within this literature, several authors have focused on the implications of reforming corporate taxes, typically by examining the effects that taxes on factors of production and rents may have on activity and welfare. More specifically, much of the literature that has looked at corporate income taxation has typically concentrated on quantifying the impact of replacing a corporate income tax (CIT) with taxes on capital or by considering corporate taxes that allow for full expensing of investment expenditure. This paper contributes to this literature by using the latest version of the International Monetary Fund's Global Integrated Fiscal and Monetary model (GIMF) ${ }^{1}$ to estimate the macroeconomic impact of replacing a CIT ${ }^{2}$ with a cash-flow tax (CFT) or a destinationbased cash-flow tax (DBCFT). ${ }^{3}$ It considers the reforms in both a large open economy, which may affect the global interest rate, and in all countries. Other than Keuschnigg (1991), we are not aware of any study that directly examines the replacement of an exact CIT by an exact $C F T / D B C F T$ in an open economy context, ${ }^{4}$ as the literature has tended to use proxies for both the CIT via taxes on the return to capital, and CFT/DBCFT via a combination of consumption taxes plus payroll subsidies. As Carton and others (2017a, 2017b) show, such proxies do not accurately reflect the impact that changes in CIT and DBCFT rates have on macroeconomic variables. Unlike Keuschnigg (1991) this paper is further able to examine how financial frictions of the type introduced by Bernanke, Gertler and Gilchrist (1999), BGG henceforth, interact with corporate taxes. Consequently, the paper examines the impact of corporate tax reform on corporate leverage.

${ }^{1}$ GIMF is a multi-region, forward looking Dynamic Stochastic General Equilibrium (DSGE) model with financial frictions, that incorporates a rich tax structure (see Carton and others, 2017a).

${ }^{2}$ In a pure (source-based) CIT, revenues from both domestic and foreign sales are subject to tax. In principle, all costs can be deducted from revenues to calculate the profits that form the tax base. These costs include labor, rent, capital depreciation, interest expenses, and intermediate inputs, including those that are imported. The introduction of the CIT into GIMF, allows the model to more closely resemble the corporate income tax base in many countries, so that the tax is levied on the economic profits (income) made by corporates.

${ }^{3}$ A CFT taxes the cash flows of corporates from sales after deducting the cost of labor, investment, and intermediate inputs. Under a DBCFT, revenues from exports are not subject to tax, while the cost of imports cannot be deducted, both of which relate to the destination-based component of the tax.

${ }^{4}$ Robinson and Thierfelder (2017) also consider the introduction of the DBCFT, but do not examine the impact of the tax on GDP but rather on trade and prices.

(continued...) 
The paper illustrates through model simulations the transitional and long-run impact on both macroeconomic and financial variables of such a fiscal policy shift for both the country undertaking the reform and for the rest of the world. The tax shifting can be decomposed in two components: a shift from a CIT to a CFT and the shift from an origin-based to a destination-based (DB) tax. The first component induces the corporate sector to invest more, which boosts potential output, GDP and consumption in the long run, but which crowds out consumption in the short run as households save to build up the capital stock. Contrary to a CIT which induces distortions, under a CFT, where investment expenditures are fully deducted immediately, the tax falls exclusively on rents, creating incentives to invest. In addition, shifting from an income base to a cash-flow base removes tax incentives to leverage, such that firms facing financial frictions borrow less. The second component is the shift from a case where both domestic and foreign revenues enter the taxable base calculation, to a case where only domestic revenue enter, and the elimination of the deduction for the cost of imported intermediate goods. This leads to an appreciation of the currency to offset the competitiveness boost afforded by the tax and maintain domestic investment-saving equilibrium. ${ }^{5}$ In the short run, however, under standard sticky-price assumptions, this effect is less than full, as importing firms are slow to reduce their prices in response to the exchange rate appreciation. This leads to a fall in imports in the near term driven by the initial decline in consumption as well as the delayed pass through of the currency appreciation into import prices. For the rest of the world, exports to the country undertaking the reform decline in response to the lower import demand despite the exchange rate appreciation.

Both components are present in the simulation results presented by Keuschnigg (1991). Using a stylized overlapping-generations, two-country, one-good open-economy model with exogenous labor supply, no liquidity constraints, no intermediate goods, rigidities, and parameters calibrated in line with the literature, Keuschnigg finds positive effects from the tax reform on capital accumulation, GDP, investment and wage growth in the long run, regardless of the level of openness.

Given the richness of GIMF, model simulations presented here also permit the examination of additional channels and spillovers beyond the channels discussed by Keuschnigg, for example, the presence of financial frictions. The abolition of the CIT interacts in a rich way with financial frictions, as interest expense deductibility partly offsets the distortionary impact of a CIT. Such deductibility results in a less distortionary impact from a CIT and hence a lower boost to investment and GDP in the long run in response to CIT cuts. At the same time, the implementation of the CFT also interacts with financial frictions as, thanks to the investment expenditure deductibility, the cost of capital drops immediately. As a

\footnotetext{
${ }^{5}$ Barbiero and others (2018) consider the impact of border adjustment in a two-country DSGE model and obtain similar results to those presented here.
} 
consequence, the value of assets on firms' balance sheets declines and, given an unchanged level of debt, raises firms' leverage leading banks to tighten lending conditions in the short run.

Moreover, when the economy undertaking the tax reform is large, there is an additional spillover effect to the rest of the world via its impact on global investment, saving and the real interest rate. Although the increase in savings in the reforming country lowers the global real interest rate in the long run, during the transition phase, higher investment demand puts mild upward pressure on global real interest rates which dampens domestic demand in nonreforming countries. The total impact on GDP in non-reforming countries is negative in the short run, but small. In the long run, however, all countries benefit from lower global interest rates, thereby boosting investment and consumption and hence GDP. With small positive spillovers from the tax reform, the analysis also shows that global GDP increases notably when all countries undertake the reform.

There has been a revival in the interest in DBCFTs stemming from the "Better Way" tax reform plan in 2016 (Tax Reform Task Force, 2016) which advocated a move to DBFCTs. However, cash flow taxes (CFTs) have long been proposed as an alternative to corporate income taxes. Brown (1948), who first advocated the CFT, the Meade Committee (1978), or King (1987) represent earlier calls in favor of CFTs as they all showed that CFTs can be less distortionary. The argument used in favor of a CFT relative to a CIT is that the former falls exclusively on rents and does not alter the economy's desired level of capital, whereas the latter (as do taxes on the return to capital) does so. ${ }^{6}$ Other noted advantages of the CFT relative to the CIT include the equal treatment of debt and equity capital under a CFT since CIT can allow for interest deductibility. ${ }^{7}$ Over various papers, Bond and Devereux (see Devereux and de la Feria, 2014), proposed the introduction of a destination basis for a CFT, arguing that these taxes would create few distortions and be similar to VAT taxes in an open economy setting without affecting labor supply.

While this paper clearly shows the benefits from moving away from a CIT to a DBCFT, several caveats should be mentioned. First, it is important to understand the limitations of the assumptions made when modelling the taxes, which were driven partly by the existing structure of GIMF and partly to simplify the algebra and the computational burden of solving the model. These limitations imply that several (possibly important) channels that could affect the macroeconomic outcomes following changes in these taxes are omitted. For instance, it is possible that firms that operate in numerous countries could modify transfer

\footnotetext{
${ }^{6}$ Although Sandmo (1971) shows that CFTs are non-distortionary only if they are not changed in the future.

${ }^{7}$ Auerbach and others (2017) provide an extensive description of the benefits of destination-based cash flow taxes. Box 1 of the April 2017 Fiscal Monitor also discusses some of the advantages of the destination-based cash flow tax.
} 
prices, relocate patents, change their financial structure, or relocate production towards the country with the less distortionary tax system. The actions could imply significant profit and/or production shifting. In addition to the broad macroeconomic implications, the resulting tax-base shifts could potentially have large implication for corporate tax revenue in different countries. However, because the model's framework does not incorporate multinational firms, these potential transmission channels are absent. Additionally, owing to simplifying assumptions related to the currency denomination of foreign liabilities, the model-based analysis cannot capture the balance sheet effects of exchange rate movements. These considerations may alter the impact of the tax reforms presented in this paper.

Second, there are important legal and political challenges to the implementation of DBCFT (IMF, 2017, and Auerbach and others, 2017). The principal obstacle is that it could be incompatible with WTO rules. Hence proponents of the DBCFT have suggested implementing it as a combination of a VAT plus a payroll subsidy since both are compliant with WTO rules (Auerbach and others, 2017). Other challenges to the introduction of a DBCFT relate to the collection of the tax and the actual implementation which are covered in detail by Devereux and de la Feria (2014) and Auerbach and others (2017).

The rest of the paper is organized as follows. Section II presents a selected summary of key papers examining CIT reform. Section III provides some intuition for why replacing a CIT by a CFT or DBCFT boosts capital, potential output and GDP. Section IV presents the tax reform experiments. ${ }^{8}$ Section V concludes.

\section{CIT REFORMS IN GENERAL EQUILIBRIUM MODELS: A REVIEW OF THE LITERATURE}

As noted above, an ample literature considering the impact of reforming corporate tax systems within general equilibrium models exists. This literature, has typically examined the effects of either reducing or abolishing CITs in the United States and Europe and usually finds significantly positive output effects, ${ }^{9}$ but does not normally examine the impact of replacing a CIT by a CFT or DBFCT. Moreover, most papers have tended to proxy corporate taxes as taxes on capital returns (KRT), see for example, the structural models used in Coenen and others (2012). This is in part due to Harberger (1962), who first examined the impact of corporate taxes on the allocation of factors of production in a perfect competition general equilibrium model without corporate debt. In that case a tax on capital returns is equivalent to a corporate income tax and as such Harberger labelled the tax on capital returns a corporate tax. Very few papers have introduced a proper CIT in DSGE models, which is part of the focus of our study.

\footnotetext{
${ }^{8}$ A brief overview of GIMF is presented in Appendix I.

${ }^{9}$ The effects on output vary across studies depending on the magnitude of the tax cut, and on how the tax cut is financed.
} 
Carroll and others (2006), using various models, find that U.S. output in the long run can increase by up to 6 percent under a progressive consumption tax plan (which taxes consumption, labor income and provides full expensing of investment and therefore proxies ingredients of a CFT). In an OLG closed-economy model, Diamond and Zodrow (2006) find that U.S. long-run output can increase by up to 5 percent under a flat tax (which also taxes labor income and business cash flows). Fehr and others (2013) consider the elimination of corporate income taxes and substituting them by taxes on consumption and labor income in an open economy OLG model with five regions and find that U.S. output increases by a little over 4 per cent in the long run. Bhattarai and others (2017), within a closed economy model, and Benzell and others (2017), within a multi-region, open-economy model, also show significant output effects in the medium run. ${ }^{10}$ While Bhattarai and others (2017) finance the tax reform with budget deficits (though no further details are provided), Benzell, Kotlikoff and LaGarda (2017) consider the replacement of a tax on capital returns (dubbed a "corporate income tax") by a combination of a consumption tax plus a labor subsidy (to proxy a DBCFT, see below for more). Diamond and al. (2014) provide significantly lower output estimates from a reduction in CITs which is financed by the reduction of investment tax incentives such as investment tax credit or accelerated depreciation allowances.

Corporate income tax reform studies for European countries include Dietz and Keuschnigg (2004), Keuschnigg and Dietz (2007) for Switzerland, Radulescu and Stimmelmayr (2007), and Radulescu and Stimmelmayr (2010) for Germany, Valkonen (2001) for Finland or de Mooij and Devereux (2011) and Álvarez-Martinez and others (2016) for EU countries. Keuschnigg and Dietz do not explicitly change the CIT rate, but consider changes to dividend and capital gains taxes (both which are part of the corporate base and affect its effective rate) and obtain an output increase of around a half a percent in the long run. Radulescu and Stimmelmayr (2010) consider the 2008 German tax reform which lowered the CIT rate by $10 \mathrm{pp}$, partly financed through an increase in the top rate of personal income and capital gains taxes, the introduction of a ceiling for net-interest expenses and the abolition of accelerated depreciation, and find negative effects on the corporate sector of around $2 \mathrm{pp}$. Valkonen (2001) found positive capital but more muted output effects associated with the Finnish tax reforms of the 1990s which separated earned income from capital income. Radulescu and Stimmelmayr (2006), Keuschnigg and Dietz (2007), de Mooij and Devereux (2011) and the Álvarez-Martinez and others (2016) examine corporate reforms that eliminate the differing treatments of debt and equity by considering an allowance for corporate equity (ACE) and a comprehensive business income tax (CBIT). Whereas ACE typically adds a

\footnotetext{
${ }^{10}$ For Benzell and others (2017), the sizeable output effects occur in the short to medium-run as wealth effects in the long-run dampen the impact of the tax reform on GDP by reducing labor supply.
} 
deductibility to firm profits stemming from returns to equity, a CBIT abolishes interest deductibility of corporate debt. As de Mooij and Devereux show, the impact on output from ACE and CBIT depend on how tax revenue shortfalls (ACE) and gains (CBIT) are financed, although on average, the impact of ACE tends to boost output, whereas a CBIT tends to lower it. ${ }^{11}$

\section{ON THE DESIRABILITY OF (DESTINATION BASED) CASH-FlOW TAXES: INTUITION}

This section provides an intuitive explanation for why CFTs are a less distortive form of raising corporate tax revenue relative to CITs. It does so by explaining the three key market distortions arising from different taxes: on capital accumulation, the labor market and trade via import and export prices. We look at each in turn, focusing on the steady state.

\section{A. Capital Market Distortions}

We start with distortions to capital accumulation in the long run. In the steady state, it can be shown that the return to capital is given by (see eg Carton and others, 2017a for a derivation within GIMF):

$R^{K}=\frac{\left(1-\tau^{C F T}\right)\left[r * f p\left(\tau^{C I T}\right)+\left(1-\tau^{C I T}\right) \delta+\tau^{C I T}\left(\frac{\pi-1}{\pi}\right)\right]}{\left(1-\tau^{C F T}-\tau^{C I T}\right)}$

where $R^{K}$ denotes the return to capital, $r$ is the real risk-free interest rate, $\delta$ is the depreciation rate of capital, $\pi$ is inflation and $\tau^{\mathrm{CIT}}$ and $\tau^{\mathrm{CFT}}$ are taxes on corporate income and cash flow respectively. We assume 100 percent depreciation allowance. $f p$ is the external financial risk premium, present when financial frictions operate, which is itself a function of corporate income taxes. In the absence of all taxes and financial frictions, the standard equation for the return to capital applies, which is increasing with the real rate and the depreciation rate:

$R^{K}=r+\delta$.

Abstracting from financial frictions, i.e. $f p=1$, and assuming that only one set of corporate taxes is in operation at a time, leaving aside important interactions between the tax rates, the relative change in the long run rental rate of capital is:

11 Álvarez-Martinez and others (2016) primarily examined the impact of a common corporate tax base (CCTB) and a common consolidated corporate tax base with formula appointment (CCCTB), with a focus on large multinational corporations. The Commission found that a CCTB lowered the cost of capital across European countries and boosted investment and GDP. When looking at a CCCTB, the Commission also considers the use of $\mathrm{ACE}$ and CBIT and finds larger output effects from ACE vs a CBIT. 
$\frac{1}{R^{K}} \frac{\partial R^{K}}{\partial \tau^{C I T}}=\frac{1}{1-\tau^{C I T}} \frac{1}{1+\left(1-\tau^{C I T}\right) \frac{\delta+\left(\frac{\pi-1}{\pi}\right)}{r+\left(\frac{\pi-1}{\pi}\right)}}>0 \quad$ with $\tau^{C F T}=0$,

$\frac{1}{R^{K}} \frac{\partial R^{K}}{\partial \tau^{C F T}}=0 \quad$ with $\tau^{C I T}=0$.

Equation (3a) shows that the return to capital is increasing with the CIT. A higher value for the return to capital, requires lower capital and hence output. Essentially in the face of a higher tax, to achieve the required after-tax return on capital the firm needs increase the pretax return. This can only be achieved by reducing the level of capital to raise its marginal product. Equation (4), which also holds in the presence of financial frictions, shows the key claim of proponents of the CFT, namely that the tax rate does not affect the required return to capital and hence investment. In the presence of financial frictions, there is an interaction effect between the external financial risk premium and a CIT. Carton and others (2017a), pages 15-17 show that:

$\frac{\partial f p}{\partial \tau^{C I T}}<0$,

since in the presence of a CIT, corporates receive a tax credit when losses are incurred. This leads to a reduction in the external finance premium as financial institutions deem borrowers to be less risky, since they get a rebate for losses, and are thus more able to repay the loan. In the presence of financial frictions, the impact of a tax increase on the return to capital is given by:

$\frac{1}{R^{K}} \frac{\partial R^{K}}{\partial \tau^{C I T}}=\frac{1}{1-\tau^{C I T}} \frac{1+\frac{r\left(1-\tau^{C I T}\right)}{r * f p+\left(\frac{\pi-1}{\pi}\right)} \frac{\partial f p}{\partial \tau^{C I T}}}{1+\left(1-\tau^{C I T}\right) \frac{\delta+\left(\frac{\pi-1}{\pi}\right)}{r * f p+\left(\frac{\pi-1}{\pi}\right)}}$,

which given (5) and an initial level of financial risk premium, $f p>1$, implies a smaller distortion from the CIT in the long run compared to a case without financial frictions.

\section{B. Labor Market Distortions}

The second key distortion emanating from taxes is in the labor market. Labor market equilibrium can be represented in GIMF by the following equation:

$L=\bar{L}-\varphi \frac{\left(1+\tau^{C}\right)}{\left(1-\tau^{L}\right)}\left(R^{K}\right) \frac{\alpha}{1-\alpha} C$,

where $L$ denote hours worked, $\bar{L}$ is a labor endowment, $R^{K}$ is the return to capital, described by (1), $C$ is consumption, $\tau^{C}$ and $\tau^{L}$ are taxes on consumption and labor income respectively and $\varphi, \alpha>0$ are parameters. As (6) clearly shows, corporate taxes do not affect the labor market directly, but do so indirectly via the return to capital, such that an increase in the return to capital, all else equal, acts to lower hours worked and hence output. In general 
equilibrium, the impact also depends on the response of consumption. Hence the overall impact will depend on the relative importance of the wealth and the substitution effect. In GIMF, like in many macroeconomic models, the substitution effect tends to be stronger, resulting in a decline to labor.

\section{Export and Import Price Distortions}

The third distortion affects import and export prices and emanates from the destination-based component of the DBCFT tax. In the steady-state import and export prices are given by:

$P^{M}=\frac{\left(1-\tau^{C I T}\right)}{\left(1-\tau^{C I T}\right)-\Omega^{D B} \tau^{D B C F T}} \varepsilon P^{*}$

$P^{X}=\frac{\left(1-\tau^{C I T}\right)-\Omega^{D B} \tau^{D B C F T}}{\left(1-\tau^{C I T}\right)} P^{Y}$,

Where $P^{M}, P^{X}, P^{*}$ and $P^{Y}$ denote import prices, export prices, world export prices and domestic prices respectively, $\varepsilon$ is the nominal exchange rate and $\Omega^{D B}$ is a dummy variable that is equal to 0 in the presence of an (origin-based) CFT, and equal to 1 when the DBCFT applies.

From (7) and (8), when the CIT is set to zero, the DBCFT acts as an export subsidy (lowering export prices, all else equal) and as an import tariff (by increasing import prices). To restore equilibrium in the external sector in response to a change in the DBCFT, the real exchange must adjust by the same amount as the tax change.

To sum up, CFT do not distort any of the equilibrium conditions, with the destination-based component of the tax (the DBCFT) only affecting the exchange rate. The CIT on the other hand is distortionary, causing a required increase the return to capital and lowering the capital stock and output. Finally, the CIT does not impact import or export prices.

\section{TAX REFORM SCENARIOS}

Four tax reform scenarios are considered. ${ }^{12}$ In the first scenario, the fiscal authorities in the large open economy, country A, replace all corporate income tax revenue by a cash flow tax. In the second scenario, country A uses a destination-based cash flow tax instead of a plain cash flow tax. In the third scenario, all countries undertake the fiscal reform using a DBCFT. In the first three scenarios a version of GIMF without financial frictions is used. To examine how the corporate income tax interacts with financial frictions, in final scenario the

\footnotetext{
12 The calibration is given in the Appendix
} 
implications of implementing the reforms is done in a version of GIMF where firms can debt finance part of the capital stock and financial frictions apply.

All scenarios assume that: first, the fiscal authorities implement the fiscal changes fully in the first year; second, there are no administrative or information costs; third, everyone understands the change and believes that it is permanent; fourth, in the first year the fiscal changes are revenue neutral and fifth, agents know that non-distortionary transfer payments are used to stabilize debt in the long run. It is further assumed that monetary policy in all regions can respond to the macroeconomic implications of the tax reform and that nominal exchange rates are fully flexible. Results are displayed for country A and the rest of the world.

\section{A. Scenario 1: Replacing a CIT by a CFT (No financial Frictions)}

Figure 1 presents both the short-run (lines) and long-run (bar) impact of the tax reform on Country A. Figure 2 presents the associated spillovers to the rest of the world (which aggregates countries $\mathrm{B}$ and $\mathrm{C}$ ). The tax reform involves two components. The first comprises the removal of the CIT, the second is the introduction of the CFT. Figures 1 and 2 break down both components with the blue lines/bars quantifying the impact of removing the CIT and the red lines/bars providing the overall impact of the reform, such that the difference between the blue and red lines represents the marginal impact of introducing the CFT. The first observation is that the CFT is not distortionary as the blue and red lines/bars are equal, with the overall impact of the reform driven by the abolition of the CIT.

The abolition of the CIT is expansionary in the long run (blue bars) since it removes a distortionary tax, as shown in equation ( $3 a$ ) above. Firms in the country undertaking the reform raise investment sharply as their desired level of capital is revised up given the increase in the effective return resulting from the abolition of the tax. The increase in the capital stock is large enough that the pre-tax physical return to capital falls in the long run (to equalize the new return to capital to the after-tax return to capital prior to the abolition of the tax). See equations (1) and (3) for more intuition. In the short run however, investment and the capital stock increase only gradually due to the presence of costly adjustment in investment.

A higher level of the capital stock raises the marginal product of labor and thus real wages. Higher real wages boost household disposable income and human wealth leading to higher consumption in the long run. However, consumption is lower in the near term as households 
increase their savings to finance the additional investment. ${ }^{13,14}$ As domestic private savings are insufficient to completely fund the increase in investment in the near term, the current account deteriorates. Eventually private savings increase by more than the increase in investment and households acquire foreign assets. ${ }^{15}$ Net foreign assets as a share of GDP are higher in the new steady state and this new level is supported by a small increase in the current account as a share of GDP (the current account decreases in the rest of the world, Figure 2).

The higher level for the capital stock implies higher potential output and GDP expands by roughly 4 percent above the initial baseline in response to raising 2.7 percent of GDP in fiscal revenue via a CFT rather than via a CIT. ${ }^{16}$ With a permanently higher level of output and domestic demand, households and firms demand more imports and thus the economy needs to export more to pay for its desired import bundle. Consequently, the real effective exchange rate is depreciated in the new steady state to maintain external balance.

The introduction of the CFT by itself has no impact on any economic variables. As equations (1) and (4) make clear, absent financial frictions, the CFT does not affect the rate of return on investment and hence does not affect the desired level of the capital stock, nor does it impact labor demand. Since the introduction of the CFT merely restores the tax revenue lost from the abolition of the CIT, there is no further effect on consumption and labor supply (as household's budget constraints are left unchanged). ${ }^{17}$ This explains why the introduction of the CFT by itself does not have any effect on the economy when other corporate taxes are set to zero.

\footnotetext{
${ }^{13}$ Consumption is crowded out by the sharp increase in investment in the near-term. The sharp increase in investment leads to an expansion of domestic demand that exceeds potential output in the near term, which in turn bids up costs (wages, return to capital) and leads to an increase in inflation. The increase in inflation leads to higher real interest rates in the near term that further dampen consumption.

${ }^{14}$ In response to the corporate revenue shortfall due to the abolition of the CIT, lump-sum transfers to households fall to offset the lost revenue. By itself, this reduction lowers disposable income, but the increase in real wages associated with the increase in the capital stock, more than offsets the lower transfers and result in higher overall consumption in the long-run.

15 The increase in private savings is driven by the household sector. The abolition of the CIT increases after-tax dividends and hence the non-human wealth of households. But this increase is offset entirely by a reduction in lump-sum transfers. Therefore, the driver of the saving increase is human wealth, which is received by both new cohorts and older ones. Since new cohorts have a lower propensity to consume, part of the increase in real wages brought about the abolition of the tax are saved.

16 These numbers are in line with previous results in the literature that document the impact of replacing the CIT: Diamond and Zodrow (2006), Fehr and others (2013), Benzell and others (2017).

${ }^{17}$ Any differences in taxable dividends are merely rebated to households via non-distortionary lump-sum transfers.
} 
Figure 1. Large Country: Replacing CIT by CFT

Percent or percentage point deviation from steady-state baseline

CIT reduction
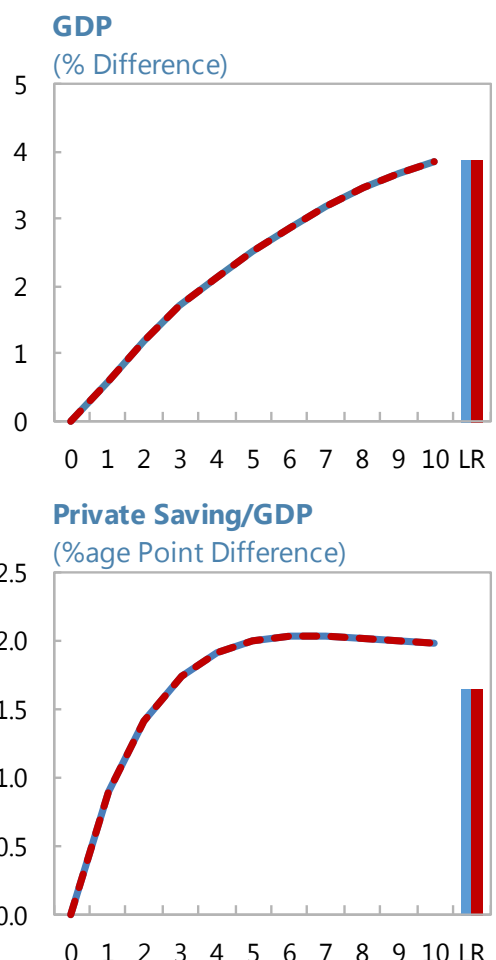

Real Effective Exchange Rate

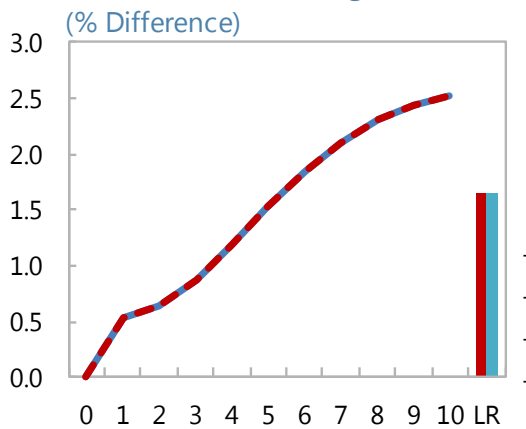

(Horizontal axis in years: $L R=$ Long Run)

CFT replacement

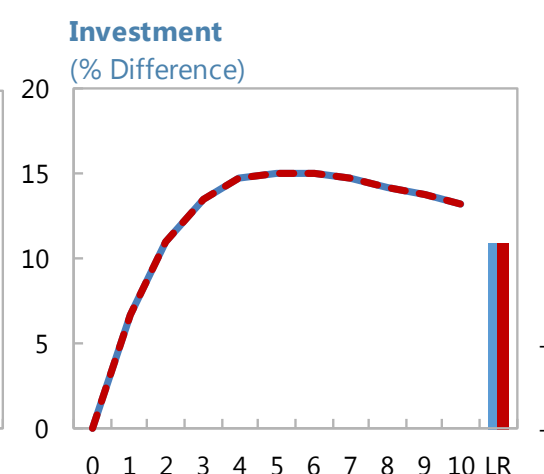

Exports

(\% Difference)

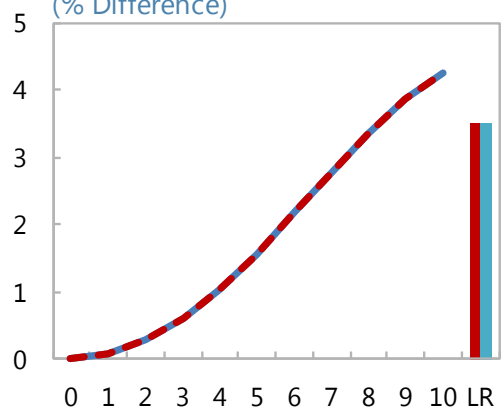

NFA/GDP

$4 \%$

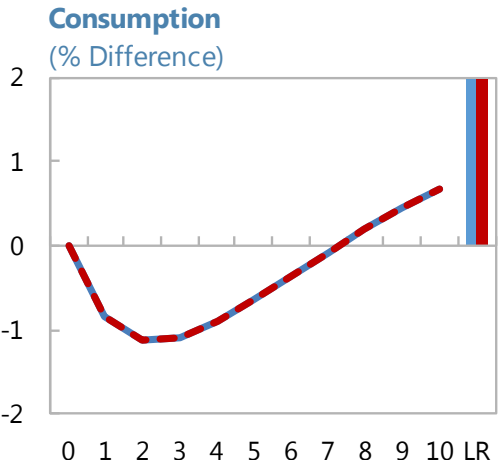

Imports

3 (\% Difference)

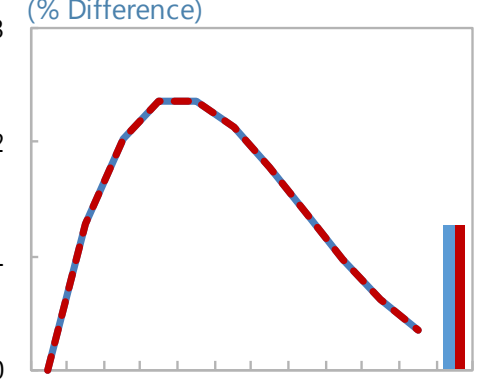

$\begin{array}{llllllllllll}0 & 1 & 2 & 3 & 4 & 5 & 6 & 7 & 8 & 9 & 10 & \text { LR }\end{array}$ Physical Return to Capital (\%age Point DIfference)

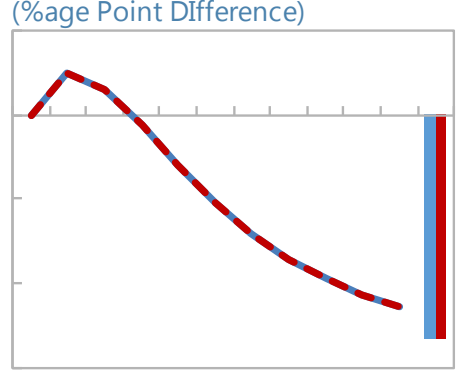

$\begin{array}{lllllllllllll}0 & 1 & 2 & 3 & 4 & 5 & 6 & 7 & 8 & 9 & 10 & \text { LR }\end{array}$

Source: GIMF simulations.

Turning next to the spillover effects from the tax reform, the increased demand for investment by the large country results in a near-term increase in exports in the rest of the world and a parallel improvement in the current account. Because global real interest rates must rise to induce the increase in global savings required to fund the higher investment, domestic demand in the rest of the world declines, more than offsetting the impact of higher exports on output in the near term. Further out, however, consumption and investment are boosted by lower global real interest rates (in response to additional private savings in Country A), and by a terms of trade improvement, in response to the appreciation of the real exchange rate which makes imports from Country A cheaper. 
Figure 2. Rest of the World: Spillovers from Replacing CIT by CFT

Percent or percentage point deviation from steady-state baseline

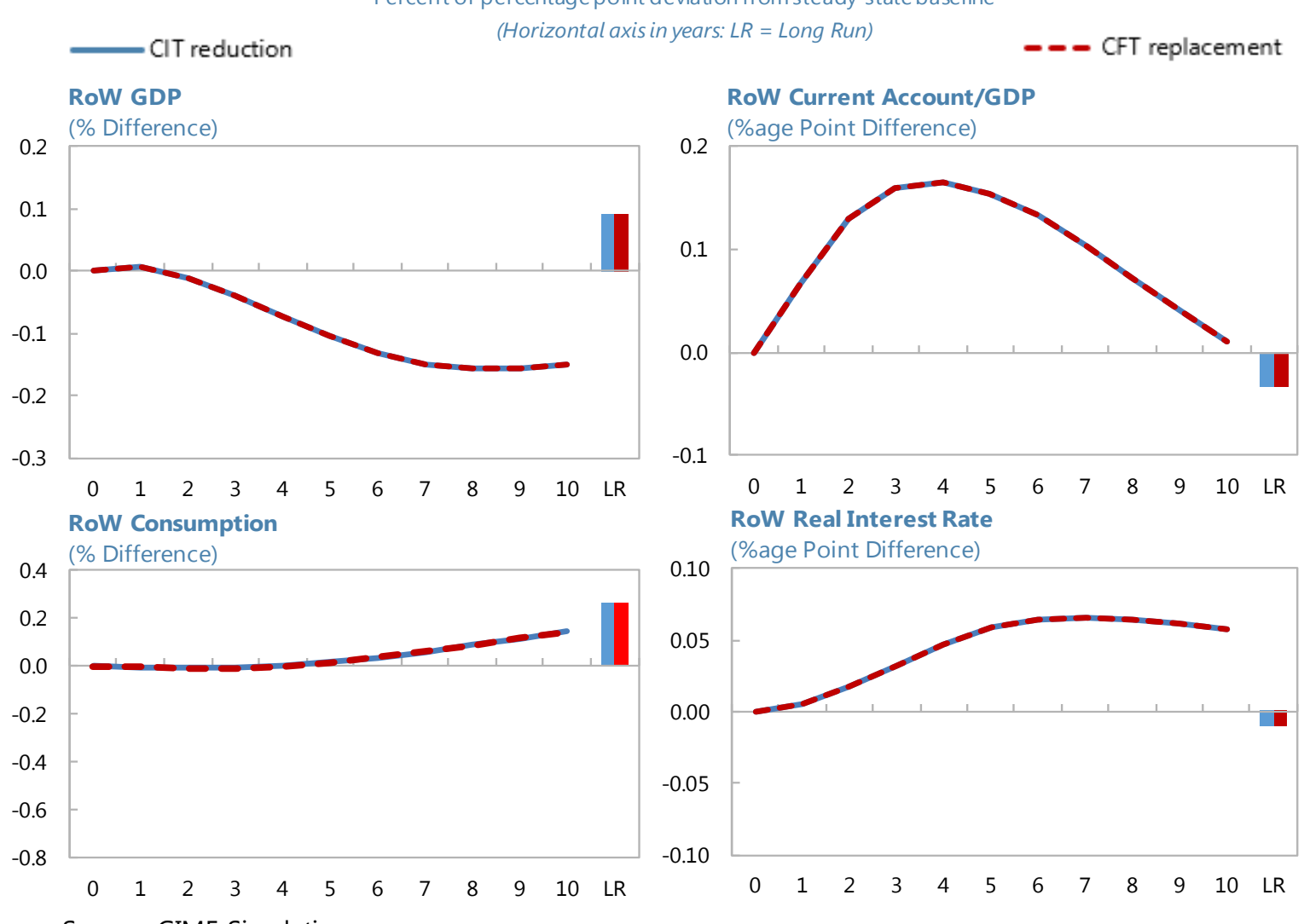

Source: GIMF Simulations.

\section{B. Scenario 2: Replacing a CIT by a DBCFT (No financial Frictions)}

Here a reform that replaces a CIT by a DBCFT is examined. Figure 3 presents both the shortrun (lines) and long-run (bar) impacts of the tax reform on Country A. Figure 4 presents the associated spillovers. The tax reform involves three components, the first two were already examined when replacing the CIT by a CFT (Figures 1 and 2 above). The third component comprises the introduction of the border adjustment, which shifts the taxable base from one that comprises both domestic and foreign revenues, to one where only domestic revenues enter. This also entails eliminating the deduction for the cost of imported intermediate goods in the calculation of the taxable base. Since the first two components are identical, Figures 3 and 4 compare the impact of the CFT reform to that of the DBCFT, with the difference reflecting the impact of the border adjustment. As before, the red lines/bars provide the overall impact of the CFT reform, and the black lines/bars provide the overall impact of the DBCFT. The first observation is that there is no difference between the CFT and DBCFT in the long run except for the real exchange rate, which appreciates with the DBCFT. There are significant differences in the near term in response to rigidities that slow the passthrough of the appreciation of the real exchange rate into import prices. We now provide further intuition for the effects, building on Carton and others (2017a). 
In the long run, the addition of the destination-based component to the CFT only affects the real exchange rate as all other macro variables remain unchanged. In GIMF, international trade is conducted through specialized firms. Exporting firms buy domestic intermediate and final goods and sell them in foreign markets. They set prices in the market that they export to. Importing firms buy a basket of foreign goods to produce imported intermediate and final goods bundles. A DBCFT affects the pricing behavior of exporting and importing firms in addition to affecting their dividends, see equations (7) and (8) for example.

Under a source-based system, both domestic sales and exports are taxed by the CFT, whereas only domestic sales are taxed under a DBCFT. Sales of exporting firms in foreign markets are not taxed at all under a DBCFT. However, intermediate goods and other domestic input costs give the right to a tax deduction. Therefore, exporting firms receive a tax benefit from their foreign sales under a DBCFT. Under monopolistic competition, this benefit is eventually passed through into a lower export price in the long run, but not so in the near term when prices are sticky. For the importing firm, however, the cost of imported intermediate inputs is no longer deductible from their tax base. Hence, the price of a good entering the country that is imposing the DBCFT is increased by the tax as it enters the country. Thus, the DBCFT reproduces the price implications of a depreciation of the exchange rate. Maintaining balance in the current account and thus the desired holdings of net foreign assets requires a compensatory real appreciation of the currency.

In the short run, the DBCFT not only has implications for the real exchange rate as noted earlier, but also on the external sector. The real exchange rate appreciates immediately in response to the destination-based component to help maintain external stability. In the short run however, the presence of sticky prices implies that the exchange rate appreciation is not immediately passed through into export and import prices. Thus, imports initially fall by more under a DBCFT relative to the case of a simple CFT and net exports provide some additional demand support in the near term amplifying the increase in output. ${ }^{18}$ The current account deteriorates (Figure 3) since the DBCFT results in a deterioration of the terms of trade on impact (after-tax export prices fall, whereas after tax import prices increase). As import and export prices adjust, the current account improves, driven by higher private sector savings as discussed under the case of a CFT.

The spillover effects to the rest of the world are also different in the short run vs the long run when comparing a CFT to a DBCFT (Figure 4). In the short run, the decline in imports in country A results in sizeable reduction in exports and output in the rest of the world relative to the case of CFT reform. As was the case under the CFT reform, higher global real interest rates in the near term still dampen consumption and investment in the rest of the world. In the

\footnotetext{
18 Despite the temporary improvement in export competitiveness brought about by the tax, exports do not increase as much relative to the pure CFT. This reflects weaker domestic demand in the rest of the world that is largely driven by the income shock given by the decline in country A's import demand.
} 
long run, as under a CFT, consumption and investment are boosted by lower real global interest rates (in response to additional private savings in Country $\mathrm{A}$ ), and by a terms of trade improvement owing to the decline in the price of imports from Country A. The currency depreciation doesn't fully offset the decline in export prices from Country A arising from the introduction of the destination-based component.

Figure 3. Large Country: Replacing CIT by DBCFT

Percent or percentage point deviation from steady-state baseline
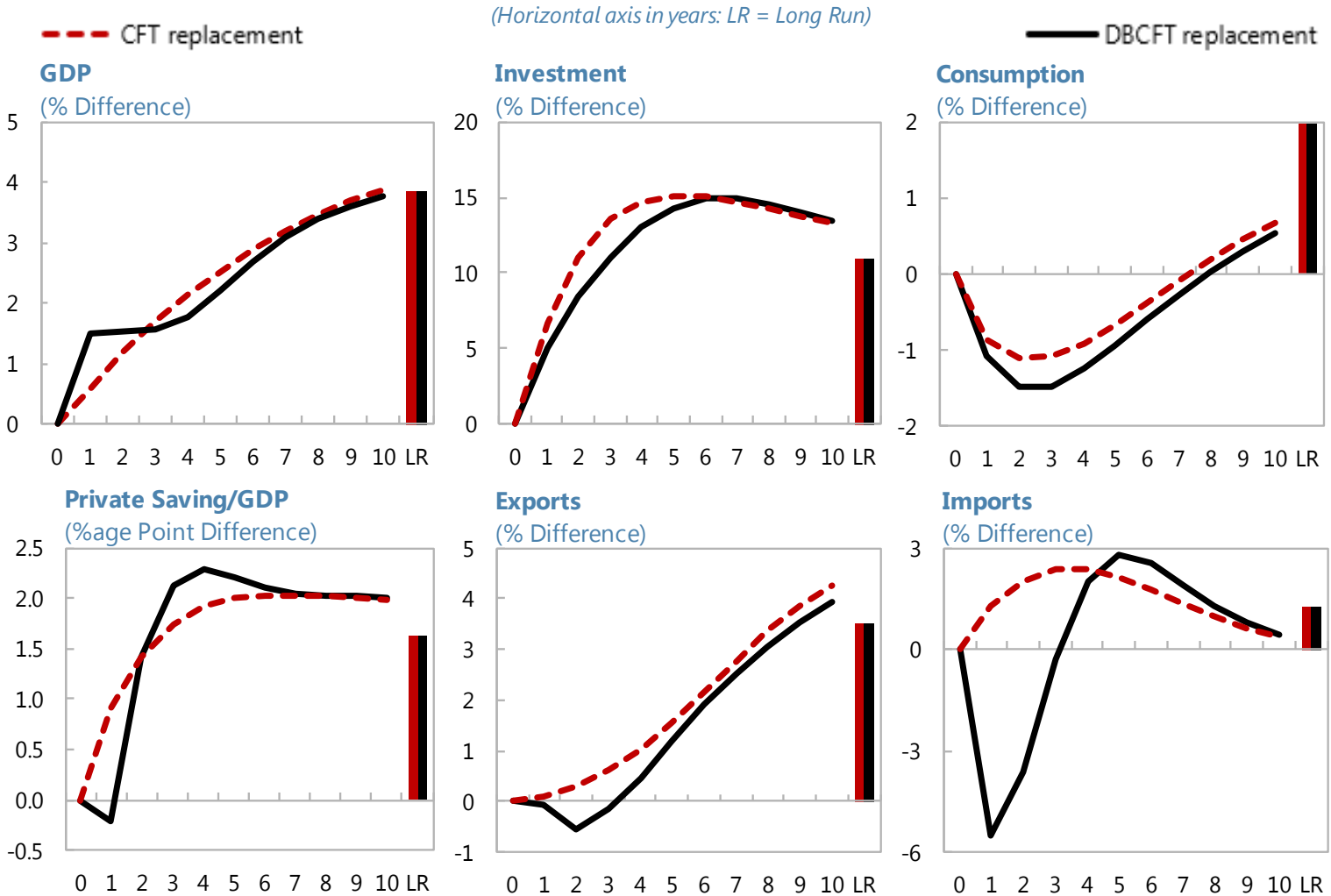

$\begin{array}{llllllllllll}0 & 1 & 2 & 3 & 4 & 5 & 6 & 7 & 8 & 9 & 10 & \text { LR }\end{array}$ Exports

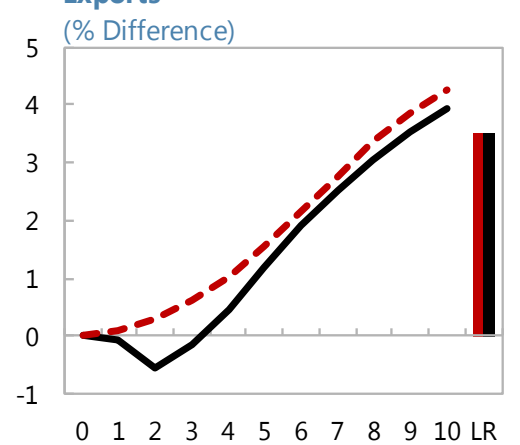

$$
\text { Imports }
$$
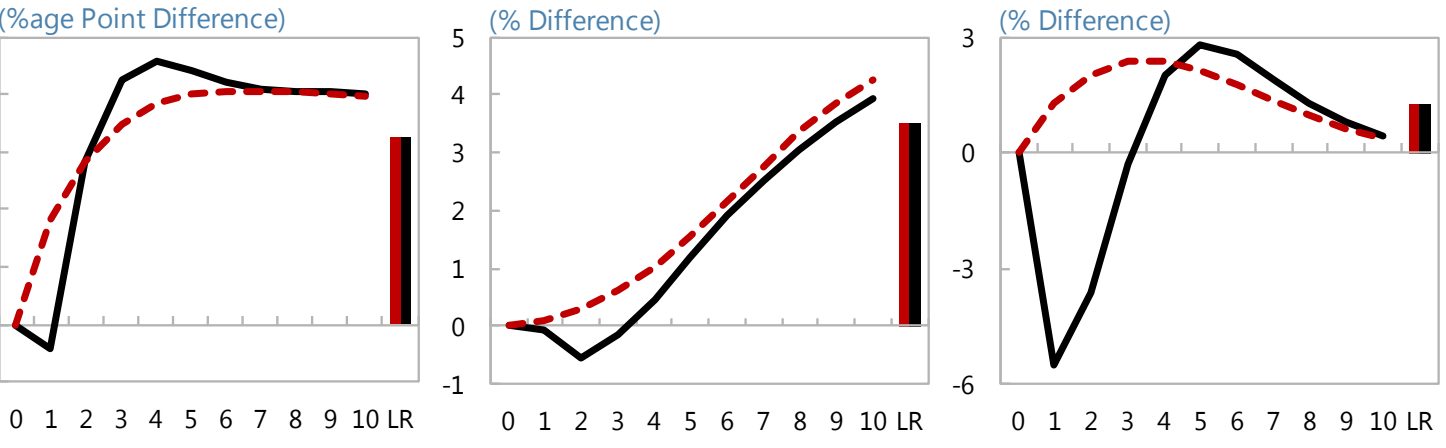

Real Effective Exchange Rate
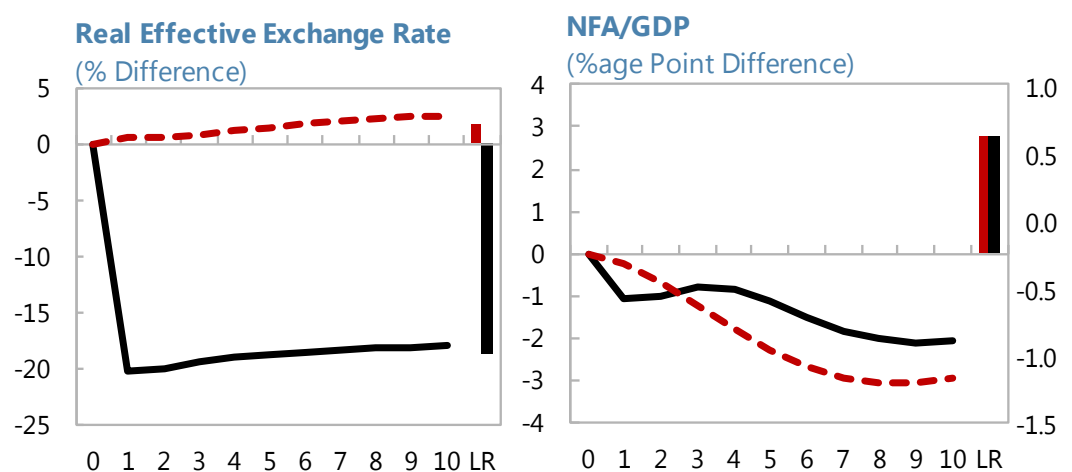

$\begin{array}{lllllllllllll}0 & 1 & 2 & 3 & 4 & 5 & 6 & 7 & 8 & 9 & 10 \mathrm{LR}\end{array}$

Physical Return to Capital

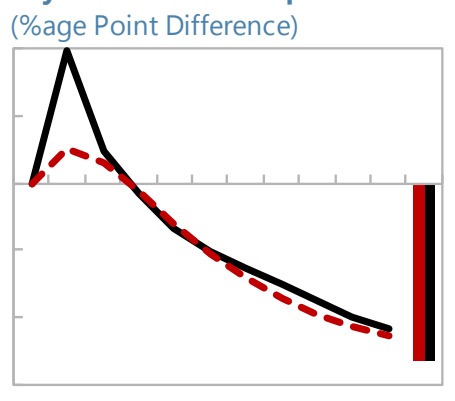

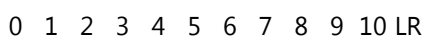

Source: GIMF simulations. 
Figure 4. Rest of the World: Spillovers from Replacing a CIT by DBCFT

Percent or percentage point deviation from steady-state baseline

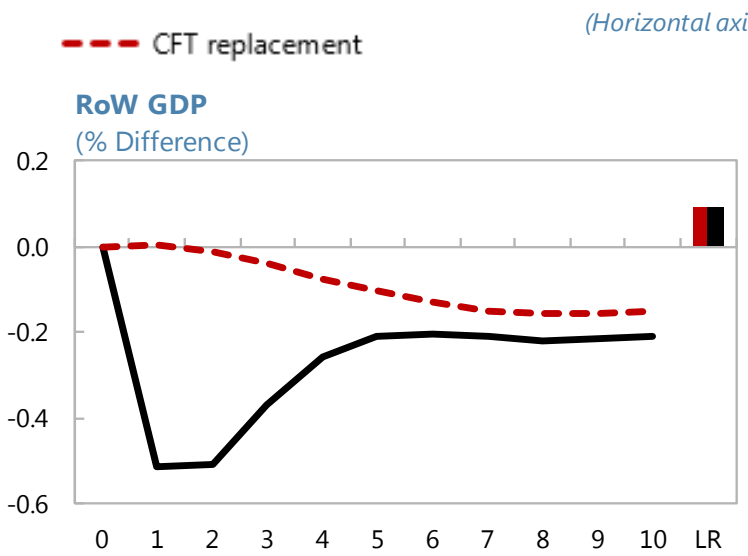

years: $L R=$ Long Run)

DBCFT replacement

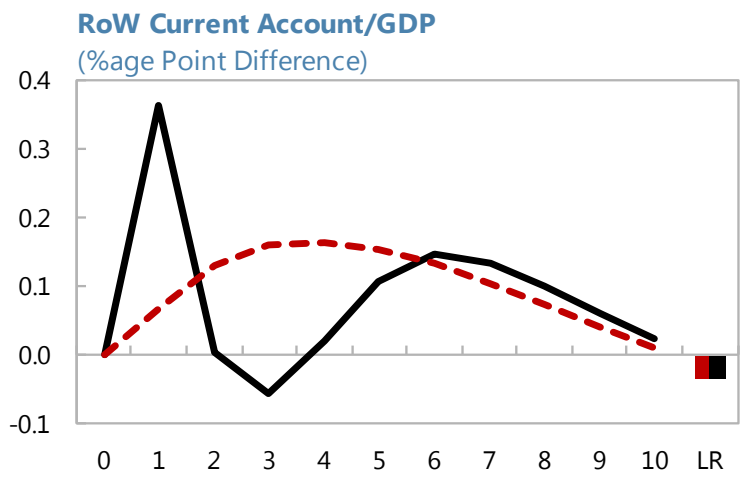

RoW Consumption
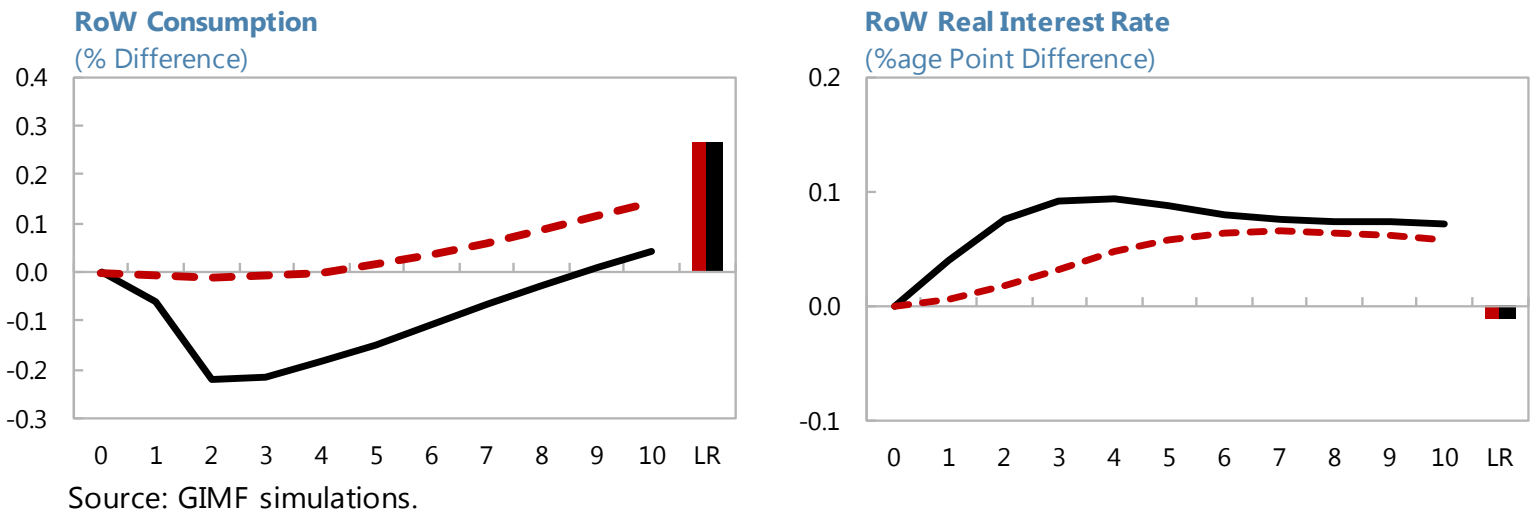

\section{Scenario 3: All Countries Replacing a CIT by a DBCFT (No Financial Frictions)}

The third scenario examines the effects of all countries undertaking the same reform at the same time. Figures 5 and 6 present the results, with green lines/bars representing the case when all countries undertake the reform and the black lines/bars when country A does so unilaterally (as shown in Figures 3 and 4).

The propagation mechanism is similar in this case to the case where one country undertakes the reform: the abolition of the CIT tax and introduction of the DBCFT tax induces firms in all countries to raise their investment. However, there are some differences in both the short and the long runs. In the near term, when all countries undertake the reform, the excess demand for investment relative to savings is larger and results in higher global real interest rates (Figure 6) that further crowd out consumption in all countries and dampen investment in country A relative to the case when country A took the reform unilaterally. The reduction in global consumption, and the introduction of the border adjustment result in a decline in country A's exports. As a result, GDP declines in the near term in country A. Country A's real exchange rate does not appreciate as the destination-based component of the tax affects all countries symmetrically. In the long run, when all export and import prices adjust, the net foreign asset positions and current accounts are unchanged. 
The impact on all domestic variables (consumption, investment, exports, imports and GDP) in the long run is nonetheless greater for country A, relative to the case when country A undertakes the reform by itself. On the export side, this is driven by higher consumption, investment by the rest of the world, as all countries gain from eliminating a distortionary tax. Country A's investment benefits not only from the additional output needed to support exports but also from even lower global real interest rates in the long run, which also boost private consumption. ${ }^{19}$

Figure 5. All Countries: Replacing CIT by DBCFT

Percent or percentage point deviation from steady-state baseline

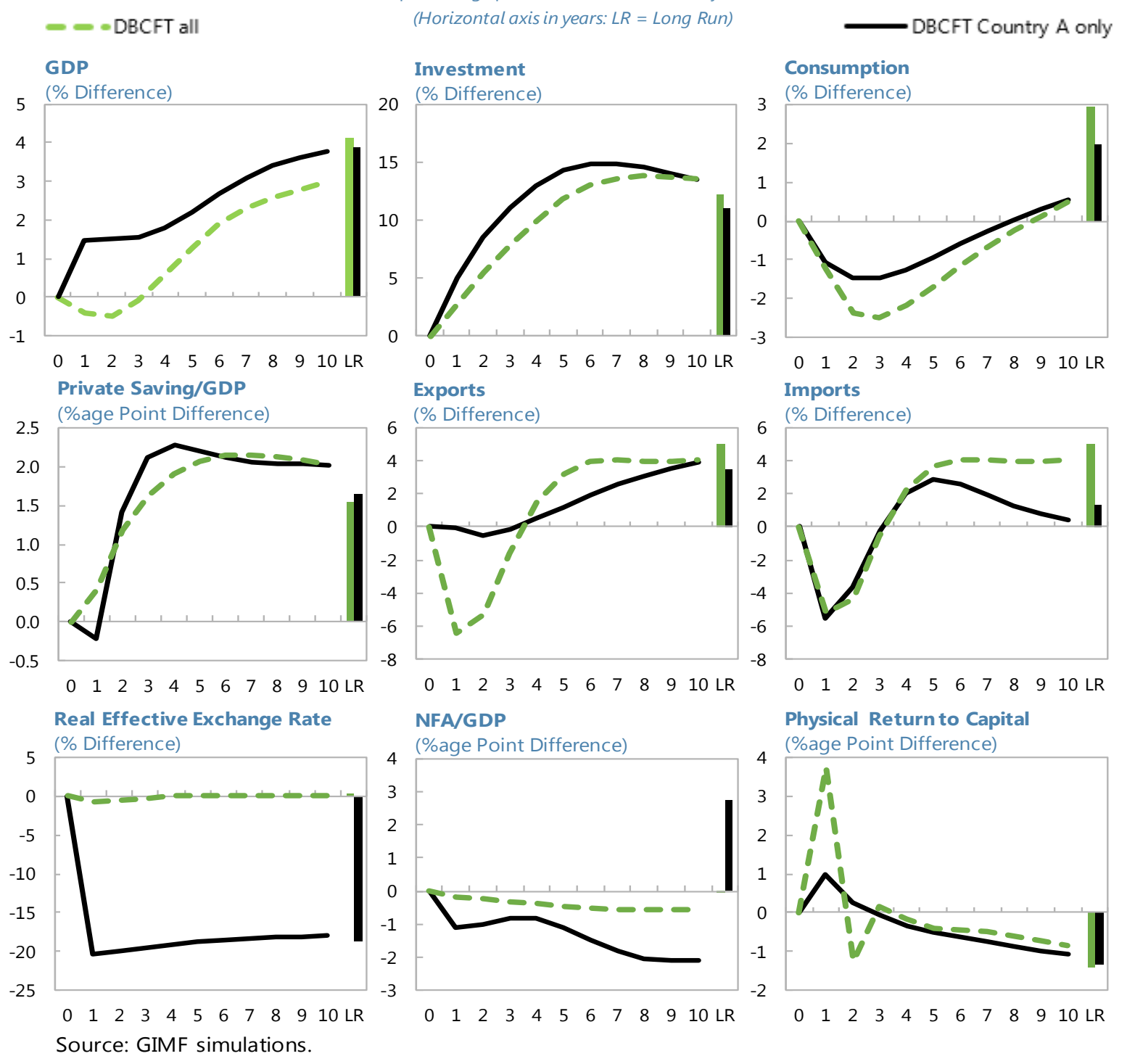

19 The decline in global real rates is driven by higher global household savings, consistent with arguments given in footnote 16 . 
Figure 6. Rest of the World: All Countries replace CIT by DBCFT

Percent or percentage point deviation from steady-state baseline

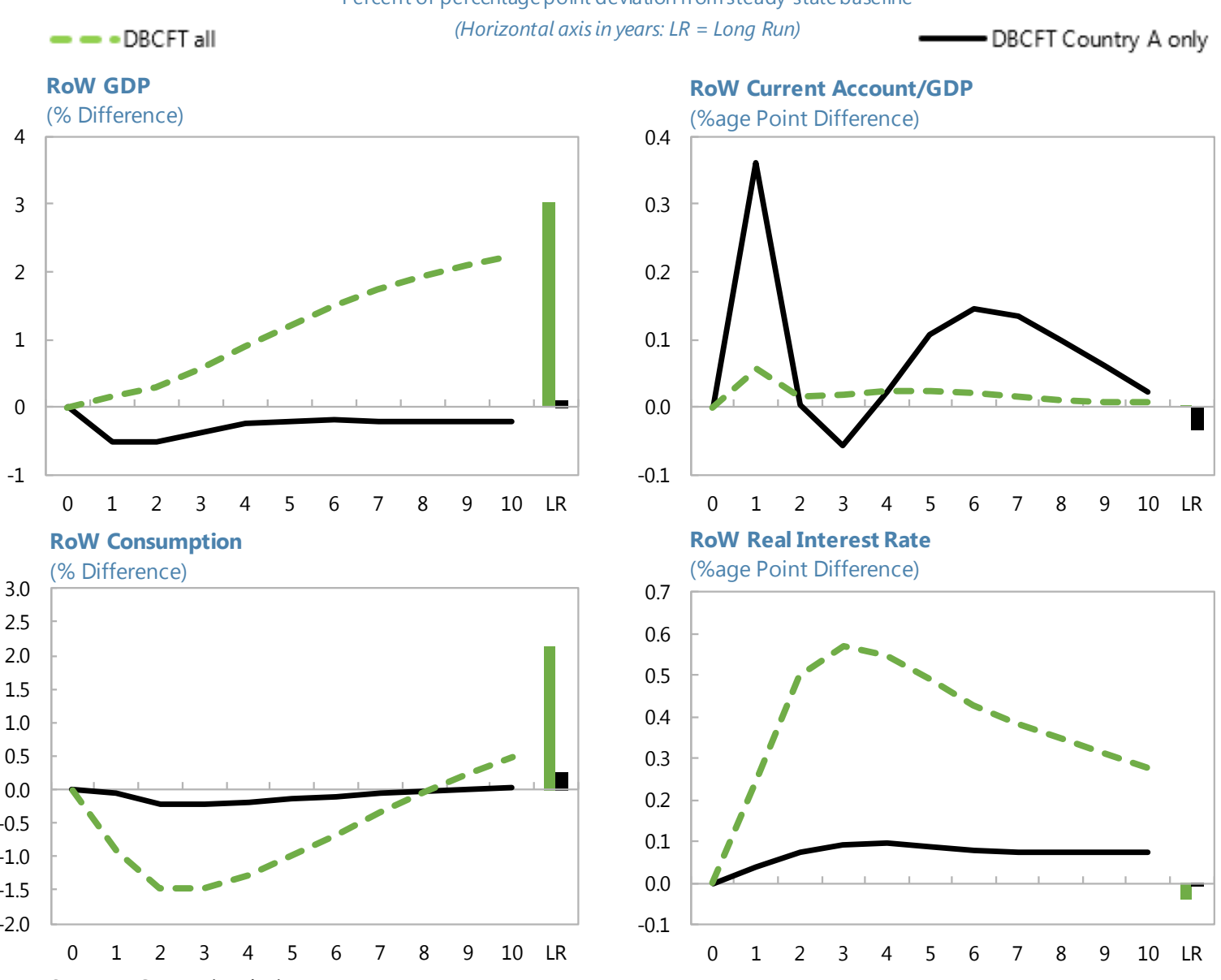

Source: GIMF simulations.

\section{Scenario 4: Replacing a CIT by a DBCFT (With Financial Frictions)}

The final scenario considers only country A undertaking the reform, but in a version of the model that allows for firms to finance some of the capital stock with debt and thus financial frictions are in operation. As Carton and others (2017a) show, when firms can finance some of the capital stock with debt they are able to deduct the associated loan interest expenses from their profits under a $\mathrm{CIT}^{20}$ and hence pay lower taxes. Such a deduction represents an implicit debt subsidy that can increase after-tax returns and increase the optimal leverage ratio. This observation is depicted in equation (5) above. As a result, the abolition of the CIT removes a smaller distortion relative to the case without debt financing, and hence the increase in firms' desired capital stock is smaller. Abolishing the CIT also reduces firms'

\footnotetext{
${ }^{20}$ In many business income tax systems, profits are taxed and losses are deductible from future profits: losses do not entail an immediate rebate from tax authorities. As it is difficult to reproduce such a complex scheme in our model, it is assumed that profits and losses are included in the business income tax base each period.
} 
leverage. Additionally, the introduction of a DBCFT lowers the value of existing capital relative to future capital (since future capital is now tax deductible) thereby lowering the shadow value of installed capital (Tobin's Q). This reduces the value of the firm and further reduces corporate debt.

The presence of debt financing and financial frictions therefore changes some of the results presented in Figures 3 and 4 both in the long run and in the near term. The presence of debt financing reduces the positive GDP impact of the abolition of the CIT tax and the associated replacement by a DBCFT (Figure 7) in the long run. This occurs because relative to the case of no debt financing or financial frictions, the CIT is less distortionary given interest expense deductibility. Interest expense deductibility reduces the burden of the CIT on the firm's required return to capital. In addition, a CIT provides a tax credit when losses are incurred which reduces firm riskiness and thus the external finance premium. Thus, under debt financing and financial frictions, moving from a CIT to DBCFT results in a much smaller increase in firms' desired stock of capital. Further, with a smaller increase in the capital stock, there is a smaller increase in the marginal production of labor, real wages and hence consumption and imports.

Along the transition path, the impact of switching from a CIT to DBFCT on firms leverage interacts with financial frictions (Figure 8) producing significant differences. A permanent increase in the DBCFT (which replaces the CIT), reduces the value of firms owing to lower after-tax dividend streams, captured by the fall in Tobin's Q. The presence of investment adjustment costs, which prevents immediate adjustment, leads to Q overshooting in the near term which sharply reduces the value of the capital stock causing leverage to spike up, and thus the external finance premium increases in the near term. Consequently, investment falls sharply in the short run.

The interaction between the fall in Tobin's Q and the financial frictions is likely overestimated in GIMF as, by construction, the only asset used as collateral for a bank loan is physical capital. If the model included a more realistic definition of firm capital that included non-tangible assets (i.e. brands, reputation, management skills, etc.), shifting to a CFT would result in a smaller increase in leverage and a milder tightening in bank lending conditions in the short run, without eliminating it entirely.

Later on, a lower shadow price of capital implies a smaller balance sheet for firms to help fund with borrowing. As firms reduce their borrowing, the external finance premium declines, and investment recovers. Consumption also falls in the short term. The initial drop in investment lowers labor demand and results in lower real wages, which reduces consumption. In response to weaker domestic demand, monetary policy is eased which results in a smaller appreciation of the currency in the near term relative to the case without financial frictions. The smaller appreciation supports exports and dampens imports relative to the case without financial frictions. However, the overall net impact is a decline in GDP in the near term. 
A significant difference arises in the net foreign asset position. The change in the value of the firm and the associated decline in corporate debt outstanding has an impact on household's wealth holdings. Given the lower cost of capital, as well as the reduced incentives to finance it with debt owing to the loss of interest deductibility, domestic firms issue less corporate debt. Given the shortage of domestic private debt, OLG households demand more foreign assets to maintain their desired level of financial wealth and the current account quickly moves into surplus and country A's net foreign asset position converges to a much higher level relative to the case of no debt financing or financial frictions. 
Figure 7. Large Country: Replacing CIT by DBCFT (Financial Frictions) Percent or percentage point deviation from steady-state baseline

(Horizontal axis in years: $L R=$ Long Run)

\section{$-\infty$ DBCFT Accelerator}

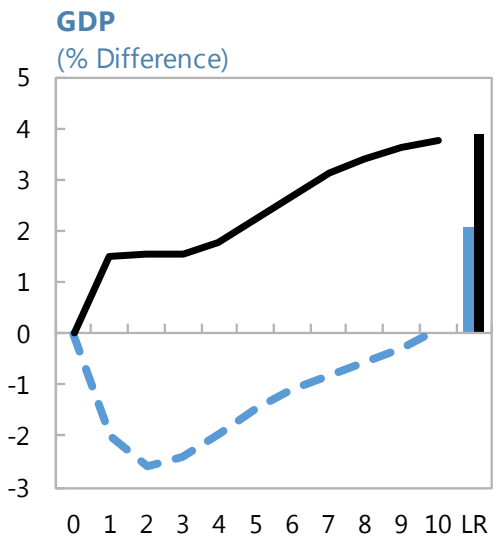

Private Saving/GDP

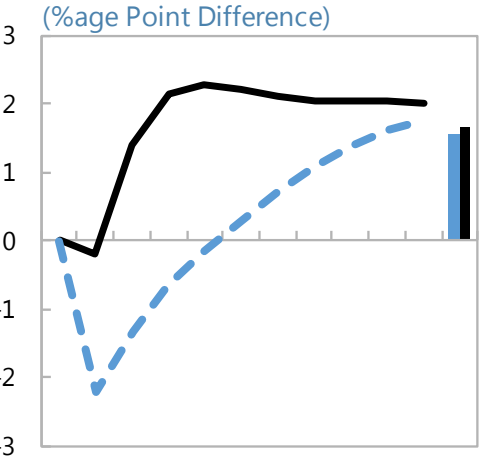

$\begin{array}{lllllllllll}0 & 1 & 2 & 3 & 4 & 5 & 6 & 7 & 8 & 9 & 10 \mathrm{LR}\end{array}$

Real Effective Exchange Rate

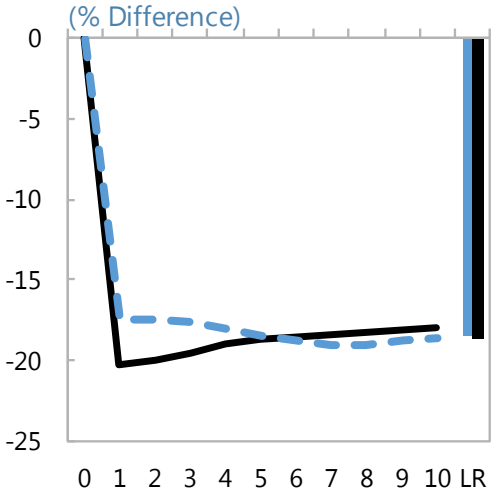

Investment

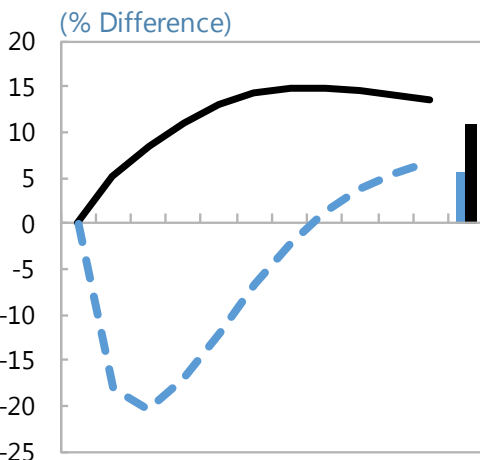

$\begin{array}{llllllllllll}0 & 1 & 2 & 3 & 4 & 5 & 6 & 7 & 8 & 9 & 10 \mathrm{LR}\end{array}$

Exports

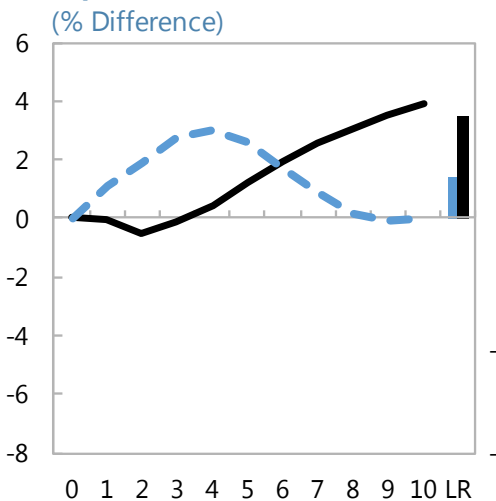

NFA/GDP

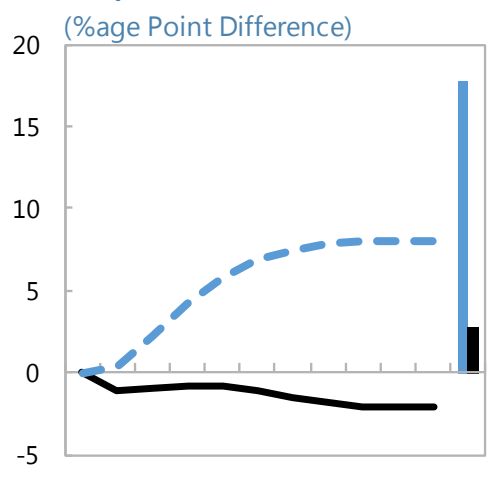

$\begin{array}{lllllllllll}0 & 1 & 2 & 3 & 4 & 5 & 6 & 7 & 8 & 9 & 10 \mathrm{LR}\end{array}$
DBCFT No Accelerator

Consumption

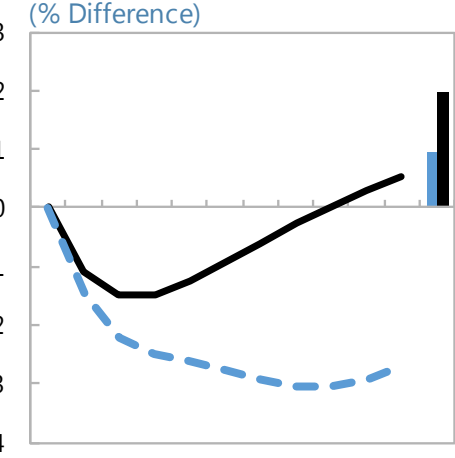

$\begin{array}{llllllllllll}0 & 1 & 2 & 3 & 4 & 5 & 6 & 7 & 8 & 9 & 10 & \text { LR }\end{array}$

Imports

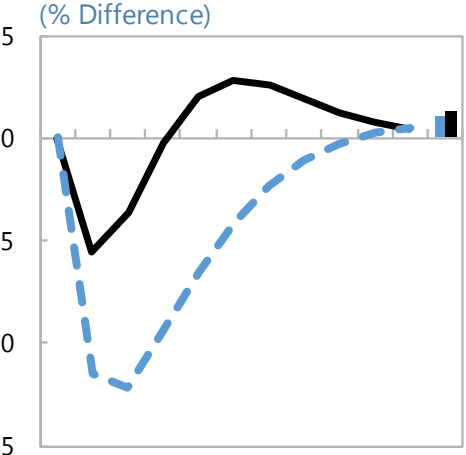

$\begin{array}{lllllllllll}0 & 1 & 2 & 3 & 4 & 5 & 6 & 7 & 8 & 9 & 10 \mathrm{LR}\end{array}$

Physical Return to Capital

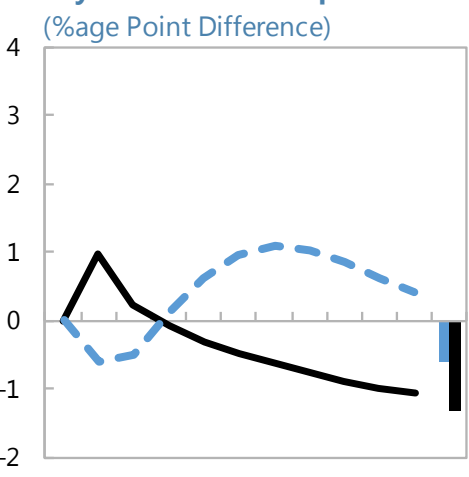

$\begin{array}{lllllllllll}0 & 1 & 2 & 3 & 4 & 5 & 6 & 7 & 8 & 9 & 10 \mathrm{LR}\end{array}$

Source: GIMF simulations. 

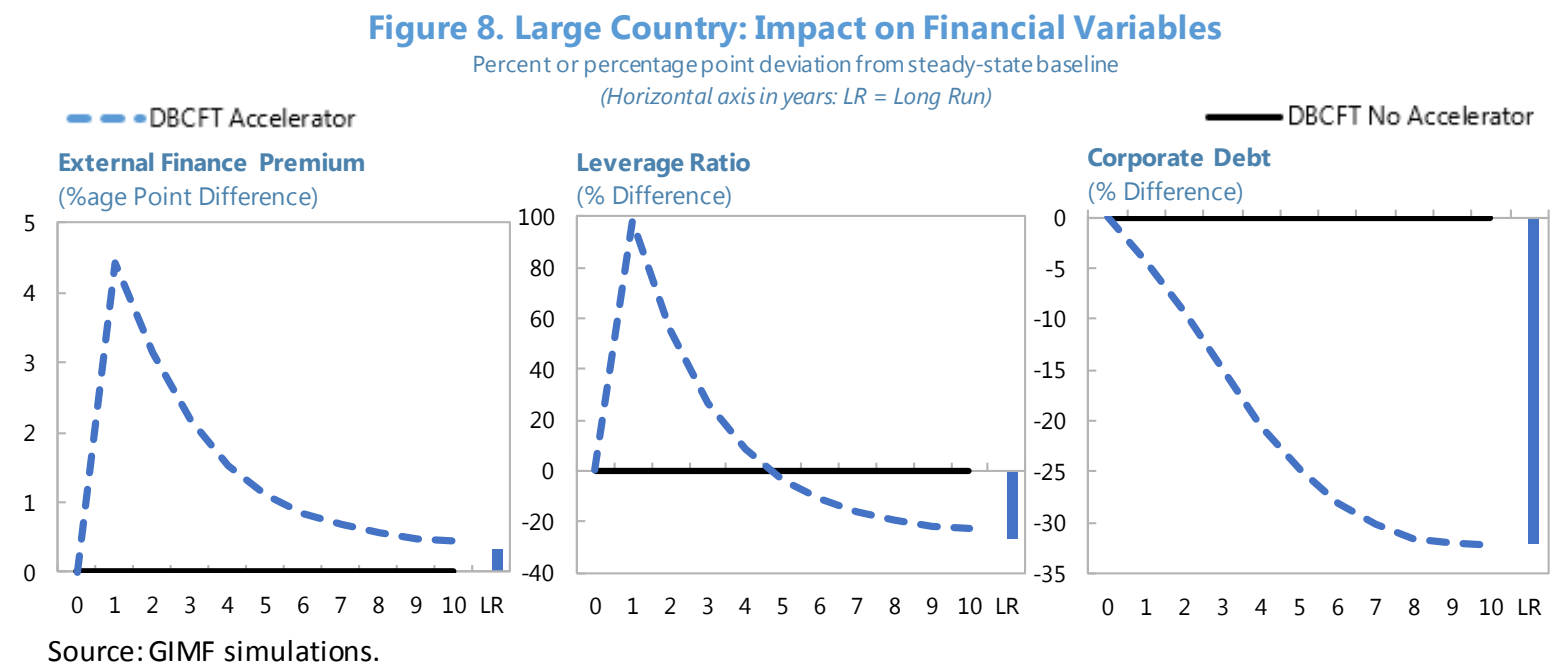

Source: GIMF simulations.

\section{Conclusions}

This paper examines the implications of replacing a corporate income tax by cash flow taxes and shows that this type of reform boosts output in the country undertaking the reform and results in positive long-run spillovers to the rest of the world. The paper documents the transmission mechanism of the reform, which propagates through the removal of a distortion on the required return to capital that serves to boosts investment, potential output and consumption. The rest of the world benefits from the additional demand for imports by the reforming country, an improvement in their terms of trade, and lower global interest rates in response to increased savings in the reforming country. ${ }^{21}$

The overall impact of the reform depends on the type of cash flow tax and on whether financial frictions are present. When the cash flow tax includes a border adjustment, and both import and export prices are sticky, the reforming country benefits from an additional nearterm output boost driven by stronger exports and weaker imports. This boost disappears once import and export prices fully adjust. In the presence of financial frictions, the benefits of the reform are significantly reduced, as the corporate income tax that is being abolished is less distortionary owing to the deductibility of interest expenses. Further, interacting with the financial friction results in an increase in the external finance premium that mitigates some of the benefits on the return to capital. Additionally, the presence of financial frictions leads to a near-term decline in output in the country undertaking the reform as the increase in the external finance premium overshoots its long-run increase because of the impact of the reform on the value of firms' capital and leverage ratios. Finally, the paper illustrates that when all countries undertake the same reform, the benefits from the tax reform are larger.

\footnotetext{
${ }^{21}$ When the country undertaking the reform is small, the increased household savings stemming from the reform are small at the global level, resulting in a smaller real interest rate decline.
} 


\section{REFERENCES}

M. T. Álvarez-Martinez, M. T., S. Barrios, D. d'Andria, M. Gesualdo, D. Pontikakis and J. Pycroft 2016, Modelling corporate tax reform in the EU: New calibration and simulations with the CORTAX model, Working Paper N. 66 - 2016, Taxation papers, Joint Research Center of the European Commission - IPTS.

Anderson, D., Hunt, B., Kortelainen, M., Kumhof, M., Laxton, D., Muir, D., Mursula, S. and S. Snudden, 2013, "Getting to Know GIMF: The Simulation Properties of the Global Integrated Monetary and Fiscal Model", IMF Working Paper Series WP/13/55. Available at https://www.imf.org/external/pubs/ft/wp/2013/wp1355.pdf

Auerbach, A. J., Devereux, M. P., Keen, M. and J. Vella, 2017, Destination-based cash flow taxation, Working paper 17/01, Oxford University Centre for Business Taxation.

Barbiero, O., Farhi, E., Gopinath G. and O. Itskhoki, 2018, The Macroeconomics of Border Tax, NBER Working Paper 24702, National Bureau of Economics Research, June.

Benzell, S. G., L. J. Kotlikoff and G. LaGarda, 2017, Simulating Business Cash Flow Taxation: An Illustration Based on the "Better Way" Corporate Tax Reform, NBER Working Paper No. 23675, August 2017.

Bhattarai, K., Haughton, J., Head, M. and D.G. Tuerck, 2017, "Simulating Corporate Income Tax Reform Proposals with a Dynamic CGE Model", International Journal of Economics and Finance, Vol. 9(5), p.20.

Bernanke, B.S., M. Gertler, and S. Gilchrist, 1999, "The financial accelerator in a quantitative business cycle framework," in: John B. Taylor and Michael Woodford, eds., Handbook of Macroeconomics, Volume 1C. Amsterdam: Elsevier.

Blanchard, O., 1985, "Debt, deficits, and finite horizons", Journal of Political Economy, Vol. 93, pp. 223-247.

Brown, E. C., 1948, "Business-Income Taxation and Investment Incentives" in Income, Employment and Public Policy; Essays in Honor of Alvin H. Hansen. New York: W.W. Norton.

Carroll, R., Diamond, J., Johnson, C. and J. Mackie III, 2006, "A Summary of the Dynamic Analysis of the Tax Reform Options", Office of Tax Analysis, U.S. Department of the Treasury, available at https://www.treasury.gov/resource-center/taxpolicy/Documents/Report-Summary-Dynamic-Analysis-2006.pdf.

Carton, B., E. Fernández Corugedo and B. L. Hunt, (2017a), No Business taxation without model representation: Adding corporate income and cash flow taxes to GIMF, IMF Working Paper 17-259, November 2017. 
Carton, B., E. Fernández Corugedo and B. L. Hunt, 2017b, Identical Twins? Destination-Based Cash-Flow Taxes Versus Consumption Taxes with Payroll Subsidies, IMF Working Paper 17-276, November 2017.

Coenen, G., C. Erceg, C. Freedman, D. Furceri, M. Kumhof, R. Lalonde, D. Laxton, J. Lindé, A. Mourougane, D. Muir, S. Mursula, J. Roberts, W. Roeger, C. de Resende, S. Snudden, M. Trabandt, J. in't Veld, 2012, "Effects of fiscal stimulus in structural models," American Economic Journal: Macroeconomics, Vol. 4(1), pp. 22-68.

de Mooij, R. A. and M.P. Devereux, 2011, "An applied analysis of ACE and CBIT reforms in the EU", International Tax Public Finance, Vo. 18, pp. 93-120.

Devereux, M. and de la Feria, R., 2014, Designing and implementing a destination-based corporate tax, Working Papers 1407, Oxford University Centre for Business Taxation.

Diamond, J. W. and G. R. Zodrow, 2006, "Economic Effects of a Personal Capital Income Tax Add-On to a Consumption Tax", International Studies Program, Working Paper 06-29, Andrew Young School of Policy Studies, Georgia State University, Available at http://icepp.gsu.edu/files/2015/03/ispwp0629.pdf

Diamond, J. W., Zodrow, G. R., Neubig, T. and R. Carroll, 2014, "The Dynamic Economic Effects of a US Corporate Income Tax Rate Reduction", Oxford University Centre for Business Taxation Working Paper No 1405, available at http://EconPapers.repec.org/RePEc:btx:wpaper:1405.

Dietz, M. D., and Keuschnigg, C., 2004, Corporate Income Tax Reform in Switzerland. Swiss Journal of Economics and Statistics, 140(4), 483-519

Fehr, H., Jokisch, S., Kambhampati, A. and L.J. Kotlikoff, 2013,"Simulating the elimination of the US corporate income tax", National Bureau of Economic Research, Working Paper No. 19757.

IMF (2017), “A greater role for fiscal policy” in IMF Fiscal Monitor: Achieving More with Less. International Monetary Fund, 2017, April.

Harberger, A. C., 1962, "The Incidence of the Corporation Income Tax", The Journal of Political Economy, Vol. 70 (3), pp. 215-240.

Keuschnigg, C., 1991, "The transition to a cash flow income tax", Swiss Journal of Economics and Statistics, vol. 127(II), p. 113-140, June.

Keuschnigg, C. and M.D., Dietz (2007), "A Growth Oriented Dual Income Tax", International Tax and Public Finance, Vol 14(2), pp.191-221.

King, M. A., 1987, “The Cash Flow Corporate Income Tax" in The Effect of Taxation on Capital Accumulation, Martin Felstein ed., University of Chicago Press, p. 377-400. 
Kumhof, M. and D. Laxton, 2007, "A Party Without a Hangover? On the Effects of U.S. Fiscal Deficits" IMF Working Paper Series, WP/07/202, available at http://www.imf.org/external/pubs/ft/wp/2007/wp07202.pdf

Kumhof, M. and D. Laxton, 2009a, "Simple, Implementable Fiscal Policy Rules," IMF Working Paper Series, WP/09/76 (April 2009), available at http://www.imf.org/external/pubs/ft/wp/2009/wp0976.pdf

Kumhof, M. and D. Laxton(2009b), "Fiscal Deficits and Current Account Deficits," IMF Working Paper Series, WP/09/237, available at http://www.imf.org/external/pubs/ft/wp/2009/wp09237.pdf

Kumhof, M., D. Laxton, D. Muir and S. Mursula, 2010, "The Global Integrated Monetary Fiscal Model (GIMF) - Theoretical Structure”, IMF Working Paper Series, WP/10/34, available at http://www.imf.org/external/pubs/cat/longres.cfm?sk=23615.0

Meade Committee, 1978, The Structure and Reform of Direct Taxation. London: Allen \& Unwin

Radulescu D. M. and M. Stimmelmayr, 2007, ACE versus CBIT: Which is Better for Investment and Welfare?, CESifo Economic Studies, CESifo, vol. 53(2), pages 294-328, June.

Radulescu, D. and M. Stimmelmayr (2010), "The Impact of the 2008 German Corporate Tax Reform: A dynamic CGE analysis", Economic Modelling, Vol. 27(1), pp. 454-467.

Robinson, S. and K. Thierfelder, 2017, "Taxes, Prices and the Exchange Rate in the DestinationBased Cash-Flow Tax (DBCFT) System", mimeo, Peterson Institute for International Economics, available at https://www.gtap.agecon.purdue.edu/resources/download/8483.pdf.

Sandmo, A. (1979), "A note on the Neutrality of the Cash Flow Corporation Tax", Economics Letters, Vol. 4 (2), 173-176.

Tax Reform Task Force, 2016, “A Better Way”. https://abetterway.speaker.gov/

Valkonen, T., 2001, "The Finnish Corporate Income Tax Reform and the Financial Strategy of Firms: A General Equilibrium Approach," Empirica, Springer; Austrian Institute for Economic Research; Austrian Economic Association, vol. 28(2), pages 219-239, June.

Zodrow, G. R., and J. W. Diamond, 2011, "Dynamic Overlapping Generations Computable General Equilibrium Models and the Analysis of Tax Policy: The Diamond-Zodrow Model." Handbook of computable general equilibrium modeling 1 (2013): 743-813. 


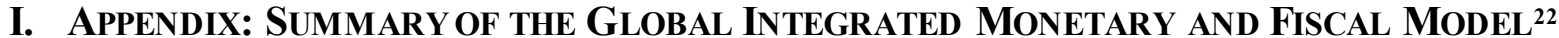

This appendix provides an overview of the Global Integrated Monetary and Fiscal model (GIMF) . More details can be found at Carton and others (2017a) and Kumhof and others (2010).

GIMF is a multicountry DSGE model with optimizing behavior by households and firms, and full intertemporal stock-flow accounting. Frictions in the form of sticky prices and wages, real adjustment costs, liquidity-constrained households, along with finite-planning horizons of households, provide a role for monetary and fiscal policy in economic stabilization.

The assumption of finite horizons separates GIMF from standard monetary DSGE models and allows it to have well-defined steady states where countries can be long-run debtors or creditors. This allows users to study the transition from one steady state to another where fiscal policy and private saving behavior play a critical role in both the dynamics and longrun comparative statics. ${ }^{23}$

The non-Ricardian features of the model provide non-neutrality in both spending-based and revenue-based fiscal measures, which makes the model particularly suitable to analyze fiscal policy questions. Fiscal policy can stimulate the level of economic activity in the short run, but sustained government deficits crowd out private investment and net foreign assets in the long run. ${ }^{24}$ Sustained fiscal deficits in large economies can also lead to a higher world real interest rate, which is endogenous.

Asset markets are incomplete in the model. Government debt is only held domestically, as nominal, non-contingent, one-period bonds denominated in domestic currency. The only assets traded internationally are nominal, non-contingent, one-period bonds denominated in U.S. dollars that can be issued by the U.S. government and by private agents in any region. Firms are owned domestically. Equity is not traded in domestic financial markets; instead, households receive lump-sum dividend payments.

\footnotetext{
${ }^{22}$ For detailed documentation on the structure of the model see Kumhof and others (2010). For details on the model's properties see Anderson and others (2013).

${ }^{23}$ See Blanchard (1985) for the basic theoretical building blocks and Kumhof and Laxton (2007,2009b) to understand their fiscal policy implications.

${ }^{24}$ Coenen and others (2010) show that GIMF fiscal multipliers for temporary shocks are similar to standard monetary business cycle models, but more importantly, GIMF can handle a much broader array of permanent shocks that can be used to study transitions from one steady state to another caused by permanent changes in the level of government debt.
} 
Firms employ capital and labor to produce tradable and nontradable intermediate goods. There is a financial sector a la Bernanke and others (1999) that incorporates a procyclical financial accelerator, with the cost of external finance facing firms rising with their indebtedness.

GIMF is multi-region, encompassing the entire world economy, explicitly modeling all the bilateral trade flows and their relative prices for each region, including exchange rates. The version used in this paper comprises of 3 regions with different calibrations for ease of exposition. The international linkages in the model allow the analysis of policy spillovers at the regional and global level.

\section{A. Household Sector}

There are two types of households, both of which consume goods and supply labor. First, there are overlapping-generation households (OLG) that optimize their borrowing and saving decisions over a 20-year planning horizon. Second, there are liquidity-constrained households (LIQ), who do not save and have no access to credit. All households pay direct taxes on labor income, indirect taxes on consumption spending, and a lump-sum tax.

OLG households save by acquiring domestic government bonds, international U.S. dollar bonds, and through fixed-term deposits. They maximize their utility subject to their budget constraint. Aggregate consumption for these households is a function of financial wealth and the present discounted value of after-tax wage and investment income. The consumption of LIQ households is equal to their current net income, so their marginal propensity to consume out of current income is unity. A high proportion of LIQ households in the population would imply large fiscal multipliers from temporary changes to taxes and transfer payments.

For OLG households with finite-planning horizons, a tax cut has a short-run positive effect on output. When the cuts are matched with a tax increase in the future, to leave government debt unchanged in the long run, the short-run impact remains positive, as the change will tilt the time profile of consumption toward the present. In effect, OLG households discount future tax liabilities at a higher rate than the market rate of interest. Thus, an increase in government debt today represents an increase in their wealth, because a share of the resulting higher taxes in the future is payable beyond their planning horizon. If the increase in government debt is permanent (tax rates are assumed to rise sufficiently in the long run to stabilize the debt-to-GDP ratio by financing the higher interest burden) this will crowd out real private capital by raising real interest rates. ${ }^{25}$

\footnotetext{
${ }^{25}$ For a more detailed description of fiscal implications in GIMF see Kumhof and Laxton (2007, 2009a, 2009b).
} 
Increases in the interest rate have a negative effect on consumption, mainly through the impact on the value of wealth. The intertemporal substitution effect from interest rate changes is moderate and has been calibrated to be consistent with the empirical evidence. The intertemporal elasticity of substitution determines the magnitude of the long-run crowding-out effects of government debt since it pins down how much real interest rates have to rise to encourage households to provide the required savings.

\section{B. Production Sector}

Firms produce tradable and nontradable intermediate goods. They are managed in accordance with the preferences of their owners, finitely-lived households. Thus, firms also have finiteplanning horizons. The main substantive implication of this assumption is the presence of a substantial equity premium driven by impatience. ${ }^{26}$ Firms are subject to nominal rigidities in price setting as well as real adjustment costs in labor hiring and investment. They pay capital income taxes to governments, wages to all households, and dividends to OLG households.

Retained earnings are insufficient to fully finance investment, so firms must borrow from financial intermediaries. If earnings fall below the minimum required to make the contracted interest payments, the financial intermediaries take over the firm's capital stock, less any auditing and bankruptcy costs, and redistribute it back to their depositors (households).

Firms operate in monopolistically competitive markets, and thus goods' prices contain a markup over marginal cost. Exports are priced to the local destination market and imports are subject to quantity adjustment costs. There are also price adjustment costs which lead to sticky prices.

Firms use public infrastructure (which is the government capital stock) as an input, in combination with tradable and nontradable intermediate goods. Thus, government capital adds to the productivity of the economy.

\section{Financial Sector}

GIMF contains a limited menu of financial assets. Government debt consists of one-period bonds denominated in domestic currency. Banks offer households one-period fixed-term deposits, their source of funds for loans to firms. These financial assets, as well as ownership of firms, are not tradable across borders. OLG households may, however, issue or purchase tradable U.S.-dollar-denominated obligations.

Banks pay a market rate of return on deposits, and charge a risk premium on loans. Because of the costs of bankruptcy (capital can only be liquidated at a discount), the lending rate

\footnotetext{
${ }^{26}$ This feature would disappear if equity was assumed to be traded in financial markets. The assumption of myopic firm behavior, and the resulting equity premium, are more plausible.
} 
includes an external financing premium, which varies directly with the debt-to-equity (leverage) ratio - the financial accelerator effect. Non-linearities imply steep increases in the risk premium for large negative shocks to net worth.

Uncovered interest parity may not hold, due to the presence of country risk premiums. The premiums can create deviations, both in the short run and the long run, between interest rates in different regions, even after adjustment for expected changes in exchange rates.

\section{International Dimensions and Spillovers}

All bilateral trade flows are explicitly modeled, as are the relative prices for each region, including exchange rates. These flows include the export and import of intermediate and final goods. They are calibrated in the steady state to match the flows observed in the recent data. International linkages are driven by the global saving and investment decisions, a by-product of consumers' finite horizons. This leads to uniquely defined current account balances and net foreign asset positions for each region. Since asset markets are incomplete, net foreign asset positions are represented by nominal non-contingent one-period bonds denominated in U.S. dollars.

Along with uncovered interest parity, and long-term movements in the world real interest rate, the magnitude of the international trade linkages is the main determinant of spillover effects from shocks in one region to other regions in the world.

\section{E. Fiscal and Monetary Policy}

Fiscal policy is conducted using a variety of expenditure and tax instruments. Government spending may take the form of either consumption or investment expenditure, or lumpsum transfers to either all households or targeted towards LIQ households. In previous versions of GIMF, revenue accrued from the taxes on labor income and capital returns, consumption taxes, and lumpsum taxes. The latest version of GIMF (Carton and others, 2017a) also allows revenue to accrue from corporate income and, crucially from cash flow taxes which also permit a destination-based component (DBCFT). A CFT taxes the cash flows of corporates from sales after deducting the cost of labor, investment, and intermediate inputs. Under a DBCFT, revenues from exports are not subject to tax, while the cost of imports cannot be deducted, both of which relate to the destination-based component of the tax. Carton and 
others (2017a) document all the changes that were made to introduce CFTs as well as other corporate taxes. ${ }^{27}$

GIMF also allows for tariffs on imported goods to be a potential source of public revenue. Government investment spending augments public infrastructure, which depreciates at a constant rate over time.

There is a fiscal policy rule which ensures long-run sustainability, while allowing for shortrun counter-cyclical policies. Changes in both labor and capital income taxes provide the instrument to put the rule into effect, but this can be replaced with other tax, transfer or spending instruments if that is considered more realistic for a specific region. First, the fiscal rule ensures that in the long run, the government debt-to-GDP ratio - and hence the deficitto-GDP ratio - eventually converges to its target level. This excludes the possibility of sovereign default, as well as the risk that out-of-control financing requirements of the government will override monetary policy. Second, the rule allows for countercyclical fiscal policy as it embodies automatic stabilizers.

When conducting monetary policy, the central bank uses an inflation-forecast-based interest rate rule. The central bank varies the gap between the actual policy rate and the long-run equilibrium rate to achieve a stable target rate of inflation over time.

\section{F. The Calibration of GIMF}

A version of GIMF that comprises three countries is used here. All countries are assumed to be identical, that is, they are governed by the same structural parameters, but only differ in size (and hence by the size of their exports/imports as a share of their GDP). The tax reforms are assumed to be undertaken in country A which is assumed to be a large open economy calibrated to be around 25 percent of the total world economy. Country B is assumed to be a

27 An important disclaimer pertains to the assumptions made when introducing the corporate taxes in GIMF (Carton and others, 2017a), which were driven by the existing structure of GIMF and by the need to simplify the computational burden of solving the model. Thus, several channels that could affect the macroeconomic outcomes following changes in these taxes are omitted. For instance, one may expect to find that multinational firms may modify transfer prices, relocate patents, change their financial structure, or relocate production towards the country with the less distortionary tax system. In addition to the broad macroeconomic implications, the resulting tax-base shifts could potentially have large implication for corporate tax revenue in different countries. However, because the model's framework does not incorporate multinational firms, these potential transmission channels are absent. Additionally, owing to simplifying assumptions related to the currency denomination of foreign liabilities, the model-based analysis cannot capture the balance sheet effects of exchange rate movements.

(continued...) 
small open economy, around 5 percent of the world economy with Country $\mathrm{C}$ representing the rest of world GDP (seventy percent). The calibration of GIMF parameters is extensively documented in Kumhof and others (2010) and in Carton and others (2017a). The table A below reports some of the key parameters as well as changes relative to the original calibration of GIMF.

The steady-state world technology growth rate is assumed to be 1.5 percent per annum and the world population growth rate is 1 percent per annum. The steady-state inflation rates for all regions are 2 percent. The long-run real interest rate is also assumed the same across countries and is set to 3 percent per annum, which implies a discount factor for households of 0.99. The OLG parameters (critical for the non-Ricardian behavior of the model), assume an average remaining time at work of 20 years, which corresponds to a probability of survival of 0.95 . The productivity decline of households as they age is set as 0.95 . The intertemporal elasticity of substitution is set at 0.5 , the elasticity of labor supply is set at 0.5 and the habit formation parameter at $0.4 .{ }^{28}$ On the production side, the depreciation rate is set at 10 percent, the labor share at 65 percent and the share of tradeable goods in production at 40 percent, in line with much of the literature.

The consumption, investment, government spending, exports, wage and capital income, taxes as a share of GDP match values observed in many OECD countries. Average mark-ups are around 10 percent, also in line with the business cycle literature. Finally, government debt as a share of GDP also matches the OECD average. Net foreign asset positions are assumed to be zero, implying balanced trade. Given the calibration, the implied initial tax rates for labor income taxes, corporate income taxes and consumption taxes are 20,14.2 and 11.3 percent respectively.

\footnotetext{
28 The share of liquidity-constrained or rule-of-thumb consumers is assumed to be less than half a percent.
} 
Table A: Key Parameters of the GIMF calibration

\begin{tabular}{|c|c|c|c|}
\hline \multicolumn{4}{|c|}{ Exogenous growth, interest rate and inflation parameters } \\
\hline Annual growth & 1.5 percent & Population growth & 1 percent \\
\hline Global real interest rate & 3 percent & Inflation Target & 2 percent \\
\hline \multicolumn{4}{|c|}{ Household Preference Parameters } \\
\hline Discount Factor & 0.99 & Int. elast. of substitution & 0.5 \\
\hline Prob. of Survival & 0.95 & Labor supply Elasticity & 0.7 \\
\hline Prod. decline & 0.95 & Habit formation & 0.4 \\
\hline \multicolumn{4}{|c|}{ Production Parameters } \\
\hline Depreciation Rate & 10 percent & Labor Share (percent of GDP) & 65 \\
\hline $\begin{array}{l}\text { Tradeable Share (percent total } \\
\text { output) }\end{array}$ & 40 & & \\
\hline \multicolumn{4}{|c|}{ Expenditure Shares (percent of GDP) } \\
\hline Consumption & 58 & Investment & 20 \\
\hline Government Spending & 22.5 & Exports (Imports) & 21 \\
\hline \multicolumn{4}{|c|}{ Other shares (percent of GDP unless stated) } \\
\hline Tax Revenue & 30 & Corporate Tax Revenue & 2.7 \\
\hline Consumption Tax Revenue & 6.5 & Labor Income Tax Revenue & 13 \\
\hline Wage Income & 65 & Capital Income & 32 \\
\hline Government Debt & 85 & NFA & 0 \\
\hline
\end{tabular}

